\title{
Ion Channel Gene Expression in the Inner Ear
}

\author{
Irene S. Gabashvili, ${ }^{1}$ Bernd H. A. Sokolowski, ${ }^{2}$ Cynthia C. Morton, ${ }^{3,4}$ and Anne B. S. Giersch ${ }^{4}$ \\ ${ }^{1}$ Hewlett-Packard Labs, 1501 Page Mill Road, Palo Alto, CA 94304, USA \\ ${ }^{2}$ Department of Otolaryngology-HNS, University of South Florida, Tampa, FL 33612, USA \\ ${ }^{3}$ Department of Obstetrics, Gynecology and Reproductive Biology, Brigham and Women's Hospital, Harvard Medical School, \\ Boston, MA 02115, USA \\ ${ }^{4}$ Department of Pathology, Brigham and Women's Hospital, Harvard Medical School, Boston, MA 02115, USA
}

Received: 3 January 2007; Accepted: 23 April 2007; Online publication: 1 June 2007

\begin{abstract}
The ion channel genome is still being defined despite numerous publications on the subject. The ion channel transcriptome is even more difficult to assess. Using high-throughput computational tools, we surveyed all available inner ear cDNA libraries to identify genes coding for ion channels. We mapped over 100,000 expressed sequence tags (ESTs) derived from human cochlea, mouse organ of Corti, mouse and zebrafish inner ear, and rat vestibular end organs to Homo sapiens, Mus musculus, Danio rerio, and Rattus norvegicus genomes. A survey of EST data alone reveals that at least a third of the ion channel genome is expressed in the inner ear, with highest expression occurring in hair cell-enriched mouse organ of Corti and rat vestibule. Our data and comparisons with other experimental techniques that measure gene expression show that every method has its limitations and does not per se provide a complete coverage of the inner ear ion channelome. In addition, the data show that most genes produce alternative transcripts with the same spectrum across multiple organisms, no ion channel gene variants are unique to the inner ear, and many splice variants have yet to be annotated. Our high-throughput approach offers a qualitative computational and experimental analysis of ion channel genes in inner
\end{abstract}

Electronic supplementary material The online version of this article (doi:10.1007/s10162-007-0082-y) contains supplementary material, which is available to authorized users.

Correspondence to: Irene S. Gabashvili · Hewlett-Packard Labs $\cdot 1501$ Page Mill Road, Palo Alto, CA 94304, USA. email: igabashvili@ yahoo.com ear cDNA collections. A lack of data and incomplete gene annotations prevent both rigorous statistical analyses and comparisons of entire ion channelomes derived from different tissues and organisms.

Keywords: hearing, ionic currents, ion channels, genome, EST mapping, expressed sequence tags, splice variants, alternative transcripts

\section{INTRODUCTION}

All fundamental physiological processes are based on the ability of cells to receive, process, and transmit signals. The signals can be as elementary as small ion movements that create electron potentials across the cell membrane by diffusing in and out of cells through ion channels. These channels allow selected ions to flow through the lipid membrane as a result of changes in the transmembrane potential, ligand binding, or when mechanical forces, temperature, or acidity reach a certain threshold.

Numerous channel variations exist, based on the ions that pass through them and the gating stimuli to which they respond. However, many share a common structural design and are built from similar protein motifs (Wei et al. 1996; Shrivastava and Bahar 2006; Guda et al. 2007). Several hundred human genes are known to encode ion channel proteins. Many of these genes produce alternative transcripts either due to different-sized untranslated regions (e.g., multiple polyadenylation signals), which result in altered translational efficiency, or due to alternative splicing of coding regions, which produce variant amino acid sequences (Coetzee et al. 1999; Lipscombe 
2005; Beisel et al. 2007). In addition, protein and transcript variants can be the result of multiple transcription start sites and alternative RNA editing sites (Ayoubi and Van De Ven 1996). Protein isoforms can substitute for each other and interact in diverse ways, reassembling into complexes with distinct sensitivities and conductance properties.

Many reviews and research articles have been dedicated to the ion channels of various tissues in health and disease (Ackerman and Clapham 1997; Shieh et al. 2000; Niemeyer et al. 2001; Bradding et al. 2003; Rosenthal and Gilly 2003; Jentsch et al. 2004; Kass 2005). Faulty ion channels are the etiology of numerous channelopathies including blindness, cystic fibrosis, diabetes, cardiac arrhythmias, hypertension, respiratory dysfunction, malignant hyperthermia, neurological and psychiatric diseases, and gastrointestinal disorders (Kass 2005; Ashcroft 2006). Directly or indirectly, ion channels are targets for many drugs in today's market (Suh and Yuspa 2005; Tai 2005) and are valuable in nanotechnology applications (Karnik et al. 2005).

Ion channels play an important role in signal transmission, and their malfunction can lead to both hearing and vestibular dysfunction (Coucke et al. 1999; Holt and Corey 1999; Kharkovets et al. 2000; Hunter 2001; Nicolas et al. 2001; Casimiro et al. 2001; Ashmore 2002; Dumont and Gillespie 2003; Marcotti et al. 2003; Rüttiger et al. 2004; Wangemann et al. 2004). Studies of voltage-gated ion channel expression in inner ear tissues (Adamson et al. 2002; Davis 2003) and expression of ionic currents during the development of hearing (Fuchs and Sokolowski 1990; Mammano and Ashmore 1996; Kros et al. 1998; Michna et al. 2003) provide evidence for the fundamental importance of ion channels in defining cellular specialization.

Here, we present hearing-related ion channel transcripts identified in both human and mouse inner ear cDNA collections and report the existence of novel ion channel gene splice variants. Most of these genes have orthologs in zebrafish and rat. We have conservatively chosen genes mapping to orthologous loci from more than one organism to eliminate potential genomic contaminants. Our findings represent a listing of ion channels produced in the ear in the highest number of copies. All of these genes and their variants are expressed in multiple species and tissues, thus representing components of conserved signal transduction circuitry. We also include a table of all ion channel genes found in any one expressed sequence tag (EST) collection from inner ear of human, mouse, rat, or zebrafish, producing the most comprehensive tabulation of hearing and balance relevant ion channel transcripts possible using these resources.

\section{METHODS}

cDNA libraries, genome, and ontology resources

To study gene expression profiles of the inner ear, we have mapped the sequences of transcripts from the only two available non-normalized, unsubtracted inner ear derived datasets: 15,048 ESTs from a human fetal cochlear cDNA library (Skvorak et al. 1999; Resendes et al. 2002) and 19,749 sequences derived from a mouse organ of Corti cDNA library (Pompeia et al. 2004). A portion of these sequences is available in GenBank (http://www.ncbi.nlm.nih.gov/Genbank/) and UniGene databases (http://www.ncbi.nlm.nih.gov/ entrez/query.fcgi?db=UniGene) as the Morton Fetal Cochlear cDNA Library (dbEST Library ID. 371; 16-22 weeks gestation) and the Mouse Organ of Corti cDNA Library (dbEST Library ID.10920; postnatal days 5-13), respectively. Mouse sequences are available also as an interactive web-based public database at NEIBank (http://neibank.nei.nih.gov).

We analyzed ESTs from publicly available normalized and/or subtracted inner ear libraries: 3,405 ESTs from a normalized fetal human cochlear library (dbEST ID.18222, Hamptonet et al. 2005, unpublished), 22,576 ESTs from a subtracted cDNA library made from 7-week and older postnatal mouse inner ear (RIKEN mouse dbEST library ID.9974; Okazaki et al. 2002; Beisel et al. 2004), 17,468 sequence reads from a subtracted embryonic zebrafish inner ear cDNA library (dbEST Library ID.10504; Coimbra et al. 2002), 1,199 EST sequences from the subtracted mouse organ of Corti library (dbEST Library ID.14415, Gerhard et al. unpublished), 1,873 ESTs from a normalized library of newborn mouse inner ear transcripts (Soares NMIE dataset, dbEST Library ID.4088, Klockars et al. 2003), and 20,090 ESTs from a normalized cDNA library made from rat vestibule (Wackym-Soares dataset, dbEST Library ID.16641, Roche et al. 2005).

Figure 1 illustrates the numbers of ion channel transcripts from the unnormalized human cochlear and mouse organ of Corti datasets. We have compared our findings to ion channel transcript frequencies extracted from the entire UniGene collection, including unnormalized libraries from brain (dbEST 11268, NIH_MGC_144: Strausberg et al. 2002, 10,700 unique clones), liver (dbEST ID 7065, NCI_CGAP_ Li9: Strausberg et al. 2002, 28,448 EST sequences, 28,331 unique clones) and kidney (dbEST 539, Barstead MPLRB1: Marra et al. unpublished; 8,060 sequences, 6,749 unique clones), massively parallel signature sequencing (MPSS, Peters et al. 2007), and rat and mouse microarrays (Rivolta et al. 2002; Lin et al. 2003; Morris et al. 2005).

All sequences were aligned to the NCBI Human Genome build 35.1 (June 2004), Mouse build 34 


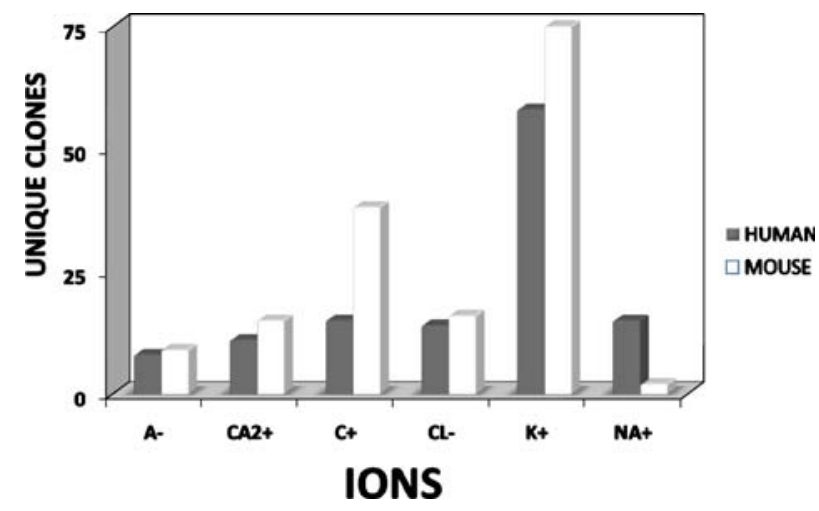

FIG. 1. Numbers of unique clones mapped to ion channel genes in non-normalized human (cochlea) and mouse (organ of Corti) cDNA libraries. $A^{-}$Anion porins (nonselective anions), $\mathrm{Ca}^{2+}$ calcium channels, $\mathrm{Cl}^{-}$chloride channels, $\mathrm{K}^{+}$potassium channels, $\mathrm{Na}^{+}$ sodium channels, $C+$ nonselective cation channels, many of which are mechanosensitive.

(March 2005), Rat build 3.4 (November 2004), and Zebrafish build 1.1 (December 2004); cDNA libraries were from UniGene Homo sapiens build \#186 and Mus musculus build \#148 (both of October 2005). Mappings were corrected according to newer genome builds H.s. 36.1 (March 2006), M.m. 36 (February 2006) D.r. Zv6 (March 2006), GenBank Release 153 (May 2006), and UniGene builds 190 (H. sapiens), 152 (M. musculus), and 90 (Danio rerio), all of May 2006. The revised manuscript was adjusted against the NCBI Reference Sequence (RefSeq) release 21 (January 2007), and Genbank release 158 (February 2007), and UniGene builds \#200 for H. sapiens (January 2007, \#161 for M. musculus (December 2006), \#160 for Rattus norvegicus (December 2006), and \#100 for D. rerio (January 2007).

Transcript variants were compared to those available in RefSeq (http://www.ncbi.nlm.nih.gov/RefSeq/); Ensemble (http://www.ensembl.org/index.html); UniProt: (http://www.pir.uniprot.org/); Vertebrate Genome Annotation Database, Vega (http://vega. sanger.ac.uk/); and ECgene (http://www.genome. ewha.ac.kr/ECgene/) and identified by the programs Twinscan (http://genes.cs.wustl.edu/) and SGP (http://genome.imim.es/genepredictions/index. html), based on mouse-human homology.

We selected all genes annotated with the term "ion channel activity" (GO:0005216) or any of its lowerlevel terms (see Fig. 2 and Supplementary Material) from the Gene Ontology (GO) database (http://www. geneontology.org/) and resources providing GO annotations (GO Annotation @ EBI, GOA (http:// www.ebi.ac.uk/GOA/); Entrez Gene, NCBI (http:// www.ncbi.nlm.nih.gov/entrez/query.fcgi? db=gene); Mouse Genome Informatics Resource, MGI (http:// www.informatics.jax.org/); Rat Genome Database, RGD (http://rgd.mcw.edu/), and the Zebrafish In- formation Network, ZFIN (http://zfin.org), as of December 2006. Note that these are evolving databases and some annotations will change over time.

\section{Computational analysis of EST data}

To map EST sequences directly to the corresponding genomes, we downloaded and installed BLAT, the BLAST-like alignment tool (Kent 2002). Genomic contaminant transcripts were determined by the presence of a poly(A) tail in an EST, and the lack of a poly(A) signal, or by the presence of a poly(A) / poly $(\mathrm{T})$ stretch in the genomic sequence flanking the mapped EST sequence (Gabashvili et al. 2005).

To determine significant differences in EST frequencies across multiple libraries, the data, which consisted of unique clone counts for ion channel genes and all genes in cDNA libraries, were arranged as $2 \times 2$ contingency tables for applying a Fisher's exact test (Supplementary Table S2). The general Chi-square test was used to compare the ratio of representative ESTs for each gene in each library. Perl and Matlab scripts were written to automate various data download and analysis tasks.

\section{RT-PCR of mouse tissue}

RNA was prepared from dissected mouse tissues (brain, cochlea, kidney and liver) using a Qiagen (Valencia, CA) RNeasy kit according to the manufacturer's instructions. Universal Reference RNA (Stratagene, La Jolla, CA) consisted of total RNA derived from 11 different mouse cell lines, including B-lymphocyte, Tlymphocyte, macrophage, kidney, liver, mammary gland, muscle, skin, testis and two embryonic lines. Equal amounts of total RNA were reverse transcribed using the Superscript III kit (Invitrogen, Carlsbad, $\mathrm{CA})$ with oligo-dT as primer following the manufacturer's protocols. To control for genomic contamination, parallel reactions were performed without reverse transcriptase. One $\mu \mathrm{l}$ of each reaction $(+/-\mathrm{RT})$ was used in PCR amplification reactions with primers specific to the known 3' UTR of Trpm3 (BQ563941, $M m .422907)$, the novel 3' UTR of Trpm3 identified in this study, the known 3' UTR of Kcna2 (CF744586, Mm.56930), the novel 3' UTR of Kcna2, the known 3' UTR of the longer Kcnmal variant (AK135652, $M m .343607$ ) and $3^{\prime}$ of the shorter mouse Kcnma1 variant identified in this work (BQ570163, Mm.343607). We note that a similar splice variant of this gene is annotated in human and rat genomes, but not in mouse. Primer sequences for each template consisted of $\left(5^{\prime}\right.$ to 3'): $\operatorname{Trpm3}$, known: forward - AGGGCTAAATT GCAAAATGAAA, reverse - TGACCAATTACAGAGGTG TTGG; Trpm3, novel: forward - TACCAGTGTGGCATT GATTCTC, reverse - GCACCTATGAAGGGGATGAT 


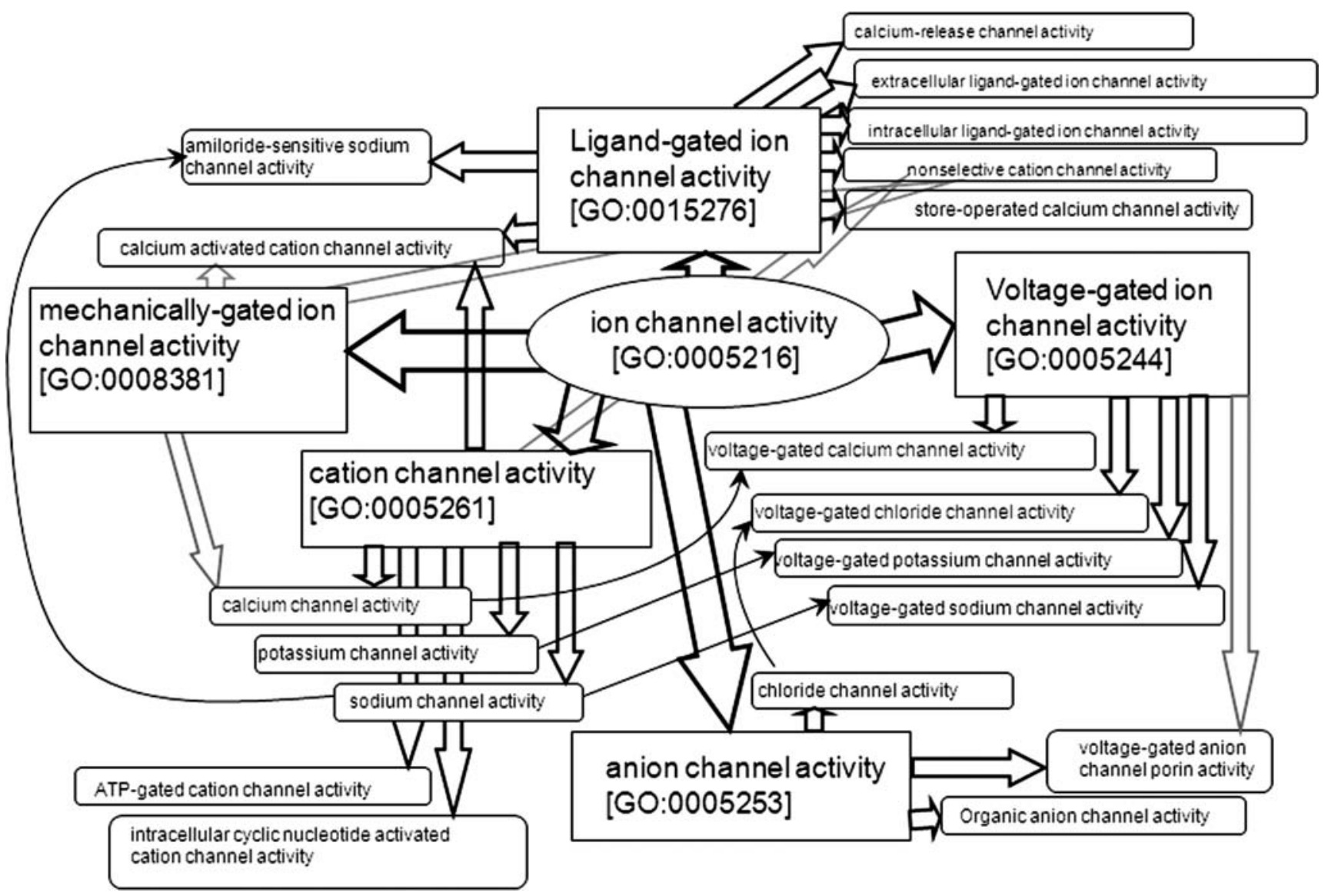

FIG. 2. Gene ontology relationships among concepts mapped to the term "ion channel activity." Grey links show relationships known from the ion channel literature that were added to the analysis in this study. Note that the concept "channel regulator activity" is not included, as it belongs to "auxiliary transport protein activity" and not to "channel or pore class transporter activity," a parent term of "ion channel activity".

TA; Kcna2, known: forward - GTCATTCTCGGTTTTGT GTTGA, reverse - CTTGGCAATTCATATTTGGTCA; KCNA2, novel: forward - TAGTTCCTGGTCACCCATAT CC, reverse - ATGGGTGTGGACATTTTATGGT; Konma1 variant 1,: forward - GTCTGTCTCATTCCTCC CACTC, reverse - CATTTTGATTTTGCATTGCTGT; Kcnmal variant 2,: forward - AAGAGCTCCTCCGTC CACTC, reverse - TTTTCATTGCTTTTTGGTTGCT; Otor: forward - TTAGCTTTCAGCGAGGAGAATC, reverse - CATTCTTCTATCCAAGGGCATC; Gapdh: forward - GGGTGGAGCCAAACGGGT, reverse - GGAGTT GCTGTTGAAGTCGCA. Amplicons for the known vs novel transcripts of each gene were designed to be of near identical size so amplification kinetics would be comparable. Reactions were performed with increasing numbers of cycles of amplification until expression level differences were observed between different tissues. Equal amounts $(14 \mu \mathrm{l})$ of each reaction were loaded onto agarose gels. PCR reactions of 31 cycles were performed for Trpm3, Kcna2 and Kcnma1. PCR reactions of 28 cycles were performed for both Gapdh (glyceraldehyde-3-phosphate dehydrogenase), a positive control for each tissue, and Otor, to demonstrate cochlear-specific transcript amplification. Each PCR product was verified by sequencing. Sequence variants were deposited in GenBank.

\section{RESULTS}

Ion channel genome

The function of most genes annotated as ion channels in the Gene Ontology database (genes annotated with the term "ion channel activity" or its child term, see Fig. 2 and Methods) was inferred computationally and not experimentally (such as direct assays, expression, interaction, or mutation studies). Supplementary Table 1 lists all genes annotated with ion channel activity in at least two vertebrate organisms, of which there are 331 entries with 313 annotated in the human genome. We assume that there is experimental evidence supporting ion channel annotation if either "Function Evidence" (ion channel activity) or "Component Evidence" (ion channel complex) is annotated with one of the experimental GO Evidence Codes in at least one of the organisms listed. Even with such assumptions, there are more computationally anno- 
tated ion channel orthologs than experimentally annotated ones (172 vs 159 among vertebrates). We note, however, that not all of these annotations are correct; experimental evidence may exist, but not documented in several cases. This table was compiled in December 2006. Over a three-month period, the number of annotations citing experimental evidence noticeably increased. This is seen from Table 1 (compiled in March 2007), which lists ion channel genes expressed in the inner ear, 162 of which are annotated experimentally vs 111 computational annotations. Over a six-month period, the number of genes annotated as ion channels changed from 342, 329, and 116 to 356,350 , and 303 in human, mouse, and zebrafish, respectively. In addition, there were 274 ion channel genes annotated in Bos taurus, 187 in Gallus gallus, and 289 in $R$. norvegicus. Many more vertebrate ion channel genes are available in the Entrez Gene database, but they are not annotated with GO terms (e.g. Pan troglodytes, Sus scrofa, or Taeniopygia guttata genomes). The number of genes linked to "ion channel activity" and shared among genomes increased from 229 to 261 for genes common to human and mouse, from 49 to 52 for genes common to human, mouse and zebrafish and from 20 to 32 orthologs in four species: human, mouse, rat and zebrafish. We note that this list will continue to evolve; its current incompleteness is due to lags in matching protein accessions to Gene IDs, incomplete Gene Ontology hierarchy and the lack of functional annotations.

\section{Ion channel transcripts in tissue-specific EST libraries}

Human. Our EST analysis and gene mapping results reveal that ion channels represent only a small fraction of genes expressed in cells. Even in the most active signal-conducting tissues such as brain, only about $2 \%$ of expressed genes are ion channels. Out of 15,048 ESTs from the human cochlea $(10,647$ clones), 169 ESTs (121 clones) align to 42 ion channel genes. We consider 28 of the 169 ESTs (20 clones) to be genomic contaminants. We excluded seven more human ESTs from further consideration as their orientation did not match the direction of the gene to which they map (all these ESTs are marked as "suboptimal member of this cluster" in UniGene). In the end, 134 human cochlear ESTs were derived reliably from ion channel transcripts.

Mouse. Another non-normalized dataset examined in the present study, a mouse organ of Corti library, contains 19,749 sequences, mainly $5^{\prime}$ ESTs, corresponding to 19,075 unique clones. We have identified 157 ion channel ESTs (61 ion channel genes) in this dataset, each of which is from a unique clone. We did not detect genomic contaminations in this dataset, primarily because of the $5^{\prime}$ nature of all the sequences. Among the ion channel genes identified, 12 (8 clones) in human and 9 ESTs in mouse represent non-selective channels conducting anions, 14 (11 clones) and 15 ESTs map to $\mathrm{Ca}^{2+}$ channels, 22 (15) and 38 ESTs map to non-selective channels conducting cations, 17 (14) and 16 ESTs map to $\mathrm{Cl}^{-}$ channels, 84 (58) and 77 ESTs map to $\mathrm{K}^{+}$channels, and 20 (15) and 2 ESTs represent $\mathrm{Na}^{+}$-conducting channels, in human and mouse respectively. Normalized human cochlear dataset (ID.18222) ESTs map to only 4 ion channel genes, but two of them (KCTD6 and GRIK4) are not present in the unnormalized library.

Rat and zebrafish. Over three hundred transcripts ( 5 ' ends of 225 unique clones) of the normalized rat vestibular cDNA library map to 115 genes annotated as ion channels in Rattus norvegicus. This number constitutes about $38 \%$ of all genes annotated as ion channels in the rat genome and about $30 \%$ of the putative vertebrate ion channel genome.

The zebrafish dataset contains 175 ion channel or ion channel-like ESTs (121 unique clones) mapped to 36 genes. Less than half of the human and mouse ESTs map to genes identified in both datasets. Even fewer human transcripts map to ion channel genes from the zebrafish inner ear library, rat vestibular cDNA library, or genes detected in cochlear mouse microarrays. Only two ion channel genes, KCNMA1 and CLIC4, are found in the cDNA libraries from all four organisms and are properly annotated in all these organisms.

Table 1 lists all ion channel genes found in any one of the studied libraries and presents several additional genes detected in microarray, MPSS, and reverse transcriptase-polymerase chain reaction (RTPCR) experiments (as of March 2007). It includes possible genomic contaminations and suboptimal alignments and presents even the weakest candidates. Obviously, it is not possible to directly compare cochlea, organ of Corti, entire inner ear, and vestibular systems to each other. Contributing to the variation between datasets is the limitation that different libraries are constructed using various tissue isolation, RNA extraction, and amplification techniques. Moreover, large-scale experiments are expected to miss genes expressed in low numbers. We find that any one of the high-throughput or lowthroughput techniques applied to ear tissues identifies expression of genes not detected by alternative methods. Nonetheless, comparison of overlapping ion channels shed light on the most highly expressed ion channel genes of the inner ear. Ion channel transcripts identified in the only two unnormalized datasets of human and mouse are listed in Table 2 
TABLE 1

Ion channel genes expressed in the inner ear as of March 2007

\begin{tabular}{|c|c|c|c|c|c|}
\hline Expressed & Genome & Gene symbol & Full name & $G O E$ & GO annotation \\
\hline $\bar{R}$ & $\mathrm{DHM}$ & $A B C C 4$ & $\begin{array}{l}\text { ATP-binding cassette, } \\
\text { sub-family C (CFTR/MRP), } \\
\text { member } 4\end{array}$ & $\mathrm{E}$ & $\mathrm{Cl}$ - channel activity \\
\hline HMR & $\mathrm{R}$ & ABCC9 & $\begin{array}{l}\text { ATP-binding cassette, } \\
\text { subfamily C (CFTR/MRP), } \\
\text { member } 9\end{array}$ & $\mathrm{E}$ & $\begin{array}{l}\mathrm{K}^{+} \text {channel activity, } \\
\text { ATP-sensitive } \mathrm{K}^{+} \text {channel complex }\end{array}$ \\
\hline Microarray & $\mathrm{R}$ & $A B P 1$ & $\begin{array}{l}\text { Amiloride binding } \\
\text { protein } 1 \text { (amine } \\
\text { oxidase, } \mathrm{Cu}^{2+} \text {-containing) }\end{array}$ & $\mathrm{C}$ & $\begin{array}{l}\text { Amiloride-sensitive } \mathrm{Na}^{+} \\
\text {channel activity }\end{array}$ \\
\hline MR & DHMR & ACCN1 & $\begin{array}{l}\text { Amiloride-sensitive } \\
\text { cation channel 1, } \\
\text { neuronal (degenerin) }\end{array}$ & $\mathrm{E}$ & $\begin{array}{l}\text { Amiloride-sensitive } \mathrm{Na}^{+} \\
\text {channel activity, } \mathrm{Na}_{\mathrm{v}} \\
\text { channel/inhibitor activity, ICA }\end{array}$ \\
\hline DMR & DGHMR & ACCN2 & $\begin{array}{l}\text { Amiloride-sensitive } \\
\text { cation channel 2, } \\
\text { neuronal }\end{array}$ & $\mathrm{E}$ & $\begin{array}{l}\text { Amiloride-sensitive } \mathrm{Na}^{+} \\
\text {channel activity, ICA }\end{array}$ \\
\hline DM & $\mathrm{HMR}$ & ACCN3 & $\begin{array}{l}\text { Amiloride-sensitive } \\
\text { cation channel } 3\end{array}$ & $\mathrm{E}$ & $\begin{array}{l}\text { Amiloride-sensitive } \mathrm{Na}^{+} \\
\text {channel activity, ICA }\end{array}$ \\
\hline Microarray & MR & A/118078 & $\begin{array}{l}\text { Expressed sequence } \\
\text { Al118078 }\end{array}$ & $\mathrm{C}$ & ICA \\
\hline$H R$ & $\mathrm{HR}$ & $A N X A 7$ & Annexin A7 & $\mathrm{C}$ & $\mathrm{Ca}_{v}$ channel activity \\
\hline $\mathrm{R}$ & M & AVEN & $\begin{array}{l}\text { Apoptosis, caspase } \\
\text { activation inhibitor }\end{array}$ & $\mathrm{C}$ & $\mathrm{Ca}^{2+}$ channel activity, ICA \\
\hline M & HMR & $B S N D$ & $\begin{array}{l}\text { Bartter syndrome, } \\
\text { infantile, with } \\
\text { sensorineural } \\
\text { deafness (Barttin) }\end{array}$ & $\mathrm{E}$ & $\mathrm{Cl}$ - channel activity \\
\hline $\mathrm{R}$ & $\mathrm{HM}$ & BTBD10 & $\begin{array}{l}\text { BTB (POZ) domain } \\
\text { containing } 10\end{array}$ & $\mathrm{C}$ & $\mathrm{K}_{\mathrm{v}}$ channel activity/complex \\
\hline $\mathrm{R}$ & BDHMR & CACNA1A & $\mathrm{Ca}_{\vee}$ channel, $\mathrm{P} / \mathrm{Q}$ type, $\alpha 1 \mathrm{~A}$ & E & ICA, $\mathrm{Ca}_{\vee}$ channel activity/complex \\
\hline Microarray & BGHM & CACNA1B & $\mathrm{Ca}_{v}$ channel, $\mathrm{N}$ type, $\alpha 1 \mathrm{~B}$ & E & ICA, $\mathrm{Ca}_{v}$ channel activity/complex \\
\hline $\mathrm{MR}$ & BDGHMR & CACNA1C & $\mathrm{Ca}_{\mathrm{v}}, \mathrm{L}$ type, $\alpha 1 \mathrm{C}$ & $\mathrm{E}$ & $\begin{array}{l}\mathrm{Ca}^{2+} \text { channel activity, } \mathrm{Ca}^{2+} \text { channel } \\
\text { inhibitor activity, } \mathrm{Ca}_{v} \text { channel } \\
\text { activity/complex, }\end{array}$ \\
\hline Microarray & BDHM & CACNA1D & $\mathrm{Ca}_{\mathrm{v}}, \mathrm{L}$ type, $\alpha 1 \mathrm{D}$ & $\mathrm{E}$ & $\begin{array}{l}\text { Dihydropyridine-sensitive } \mathrm{Ca}^{2+} \\
\text { channel activity, } \mathrm{Ca}_{v} \text { channel } \\
\text { activity/complex }\end{array}$ \\
\hline M & BHMR & CACNA1E & $\mathrm{Ca}_{\mathrm{v}}, \mathrm{R}$ type, $\alpha 1 \mathrm{E}$ & $\mathrm{E}$ & $\begin{array}{l}\text { ICA, } K_{v} \text { channel activity, } \mathrm{Ca}_{v} \text { channel } \\
\text { activity/complex }\end{array}$ \\
\hline $\mathrm{HM}$ & BHMR & CACNA1G & $\mathrm{Ca}_{\mathrm{v}}, \mathrm{T}$ type, $\alpha 1 \mathrm{G}$ & E & ICA, $\mathrm{Ca}_{v}$ channel activity/complex \\
\hline HMR & HMR & CACNA2D1 & $\mathrm{Ca}_{\mathrm{v}}, \alpha 2 / \delta 1$ & $\mathrm{E}$ & $\begin{array}{l}\mathrm{Ca}^{2+} \text { channel activity, } \mathrm{Ca}_{v} \text { channel } \\
\text { activity/complex }\end{array}$ \\
\hline $\mathrm{R}$ & $\mathrm{R}$ & CACNA2D3 & $\mathrm{Ca}_{v}, \alpha 2 / \delta 3$ & $\mathrm{E}$ & $\begin{array}{l}\mathrm{Ca}^{2+} \text { channel regulator activity, } \mathrm{Ca}_{v} \\
\text { channel activity/complex }\end{array}$ \\
\hline $\mathrm{R}$ & BDHMR & $C A C N B 1$ & $\mathrm{Ca}_{v}, \beta 1$ & $\mathrm{E}$ & $\begin{array}{l}\mathrm{Ca}^{2+} \text { channel activity, } \mathrm{Ca}^{2+} \text { channel } \\
\text { inhibitor activity, dihydropyridine- } \\
\text { sensitive } \mathrm{Ca}_{v} \text { channel activity }\end{array}$ \\
\hline HMR & BDHMR & CACNB2 & $\mathrm{Ca}_{\mathrm{v}}, \beta 2$ & $\mathrm{E}$ & $\begin{array}{l}\text { Amiloride-sensitive } \mathrm{Na}^{+} \text {channel } \\
\text { activity, } \mathrm{Ca}_{v} \text { channel activity }\end{array}$ \\
\hline MR & BHMR & $C A C N B 3$ & $\mathrm{Ca}_{v}, \beta 3$ & $\mathrm{E}$ & $\mathrm{Ca}_{\vee}$ channel activity \\
\hline $\mathrm{HM}$ & BGHMR & CACNB4 & $C a_{v}, \beta 4$ & $\mathrm{E}$ & IBID \\
\hline MPSS & GHMR & CACNG4 & $\mathrm{Ca}_{\mathrm{v}}, \gamma 4$ & $\mathrm{E}$ & $\begin{array}{l}\text { Voltage-gated channel complex, } \mathrm{Ca}_{v} \\
\text { activity/complex }\end{array}$ \\
\hline $\mathrm{R}$ & $\mathrm{D}$ & $C A L B 2$ & Calbindin 2, (calretinin) & $\mathrm{C}$ & $\begin{array}{l}\mathrm{Ca}^{2+} \text { channel activity, } \mathrm{Ca}^{2+} \text { channel } \\
\text { inhibitor activity }\end{array}$ \\
\hline HMR & $\mathrm{D}$ & CALM1 & Calmodulin 1 & $\mathrm{C}$ & $\begin{array}{l}\mathrm{Ca}^{2+} \text { channel activity, } \mathrm{Ca}^{2+} \text { channel } \\
\text { regulator activity, channel- } \\
\text { conductance-controlling ATPase } \\
\text { activity }\end{array}$ \\
\hline DHMR & $\mathrm{D}$ & CALM2 & Calmodulin 2 & $\mathrm{C}$ & $\begin{array}{l}\mathrm{Ca}^{2+} \text { channel activity, } \mathrm{Ca}^{2+} \text { channel } \\
\text { inhibitor activity }\end{array}$ \\
\hline DHR & $\mathrm{D}$ & CALM3 & Calmodulin 3 & $\mathrm{C}$ & IBID \\
\hline $\mathrm{DMR}$ & $\mathrm{D}$ & $C A L R$ & Calreticulin & $\mathrm{C}$ & IBID \\
\hline
\end{tabular}


TABLE 1 (continued)

Ion channel genes expressed in the inner ear as of March 2007

\begin{tabular}{|c|c|c|}
\hline Expressed & Genome & Gene syr \\
\hline $\begin{array}{l}\text { Microarray } \\
\text { HM } \\
\text { Microarray }\end{array}$ & $\begin{array}{l}D \\
D\end{array}$ & $\begin{array}{l}\text { CASQ2 } \\
\text { CDH1 } \\
\text { CDH10 }\end{array}$ \\
\hline $\begin{array}{l}\mathrm{HR} \\
M\end{array}$ & $\begin{array}{l}\mathrm{D} \\
\mathrm{D}\end{array}$ & $\begin{array}{l}C D H 11 \\
C D H 15\end{array}$ \\
\hline $\mathrm{R}$ & $\mathrm{D}$ & $\mathrm{CDH} 17$ \\
\hline DR & $\mathrm{D}$ & $\mathrm{CDH} 2$ \\
\hline $\mathrm{R}$ & D & $\mathrm{CDH} 23$ \\
\hline $\mathrm{HR}$ & D & CDH5 \\
\hline $\mathrm{D}$ & $\mathrm{D}$ & $\mathrm{CDH} 6$ \\
\hline Microarray & BHMR & CFTR \\
\hline
\end{tabular}

\begin{tabular}{|c|c|c|c|c|c|}
\hline Microarray & BDGHMR & CHRNA1 & $\begin{array}{l}\text { Cholinergic receptor, } \\
\text { nicotinic, } \alpha 1 \text { (muscle) }\end{array}$ & $\mathrm{E}$ & $\begin{array}{l}\text { ICA, nicotinic ACh-activated cation- } \\
\text { selective channel activity/complex }\end{array}$ \\
\hline $\mathrm{H}$ & $\mathrm{H}$ & CHRNA10 & $\begin{array}{l}\text { Cholinergic receptor, } \\
\text { nicotinic, } \alpha 10\end{array}$ & $\mathrm{E}$ & $\begin{array}{l}\text { ICA, nicotinic ACh-activated/gated } \\
\text { cation-selective channel activity }\end{array}$ \\
\hline M & GHMR & CHRNA4 & $\begin{array}{l}\text { Cholinergic receptor, } \\
\text { nicotinic, } \alpha 4\end{array}$ & $\mathrm{E}$ & $\begin{array}{l}\text { ICA, nicotinic ACh-activated/gated } \\
\text { cation-selective channel } \\
\text { activity/complex }\end{array}$ \\
\hline DMR & BDGHMR & CHRNA7 & $\begin{array}{l}\text { Cholinergic receptor, } \\
\text { nicotinic, } \alpha 7\end{array}$ & $\mathrm{E}$ & $\begin{array}{l}\text { ICA, extracellular ligand-gated ICA, } \\
\text { nicotinic ACh-activated } \\
\text { cation-selective channel activity }\end{array}$ \\
\hline M & GHMR & CHRNA9 & $\begin{array}{l}\text { Cholinergic receptor, } \\
\text { nicotinic, } \alpha 9\end{array}$ & $\mathrm{E}$ & $\begin{array}{l}\text { ICA, extracellular ligand-gated ICA, } \\
\text { nicotinic ACh-activated } \\
\text { cation-selective channel activity }\end{array}$ \\
\hline M & BGHMR & CHRNB4 & $\begin{array}{l}\text { Cholinergic receptor, } \\
\text { nicotinic, } \beta 4\end{array}$ & $\mathrm{E}$ & $\begin{array}{l}\text { ICA, extracellular ligand-gated ICA, } \\
\text { nicotinic ACh-activated } \\
\text { cation-selective channel activity }\end{array}$ \\
\hline Microarray & $\mathrm{BDHM}$ & CHRNE & $\begin{array}{l}\text { Cholinergic receptor, } \\
\text { nicotinic, } \varepsilon\end{array}$ & $\mathrm{E}$ & IBID \\
\hline Microarray & BGHMR & CHRNG & $\begin{array}{l}\text { Cholinergic receptor, } \\
\text { nicotinic, } \gamma\end{array}$ & $\mathrm{E}$ & $\begin{array}{l}\text { Nicotinic ACh-activated } \\
\text { cation-selective channel activity, } \\
\text { nicotinic ACh-gated receptor-channel } \\
\text { complex }\end{array}$ \\
\hline $\mathrm{R}$ & $\mathrm{D}$ & CIB2 & $\begin{array}{l}\mathrm{Ca}^{2+} \text { and integrin } \\
\text { binding family } \\
\text { member } 2\end{array}$ & C & $\begin{array}{l}\mathrm{Ca}^{2+} \text { channel activity, } \mathrm{Ca}^{2+} \text { channel } \\
\text { inhibitor activity }\end{array}$ \\
\hline Microarray & $\mathrm{BM}$ & CLCA3 & $\begin{array}{l}\mathrm{Cl}-\text { channel } \\
\mathrm{Ca}^{2+} \text {-activated } 3\end{array}$ & $\mathrm{C}$ & $\mathrm{Cl}-$ channel activity, voltage-gated ICA \\
\hline M & M & CLCA5 & $\begin{array}{l}\mathrm{Cl}-\text { channel } \\
\mathrm{Ca}^{2+} \text {-activated } 5\end{array}$ & $\mathrm{E}$ & $\mathrm{Cl}-$ channel activity, ligand-gated ICA \\
\hline M & HMR & CLCC1 & $\begin{array}{r}\text { Cl- channel } \\
\text { CLIC-like } 1\end{array}$ & $E$ & $\mathrm{Cl}$ - channel activity \\
\hline MR & BHMR & CLCN2 & $\mathrm{Cl}-$ channel 2 & $\mathrm{E}$ & $\mathrm{Cl}_{\mathrm{v}}-$ channel activity \\
\hline$H R$ & HMR & CLCN3 & $\mathrm{Cl}$ - channel 3 & $\mathrm{E}$ & IBID \\
\hline MR & $\mathrm{R}$ & CLCN4-2 & $\mathrm{Cl}$ - channel 4-2 3 & C & $\begin{array}{l}\mathrm{Cl}_{\mathrm{v}}^{-} \text {channel activity, } \\
\text { voltage-gated ICA }\end{array}$ \\
\hline $\mathrm{H}$ & BHMR & CLCN5 & $\begin{array}{l}\text { Cl- channel } 5 \\
\text { (nephrolithiasis } \\
\text { 2, X-linked, } \\
\text { Dent disease) }\end{array}$ & $\mathrm{E}$ & $\mathrm{Cl}_{\mathrm{v}}-$ channel activity \\
\hline M & $\mathrm{HM}$ & CLCN6 & Cl- channel 6 & C & IBID \\
\hline M & BGHM & CLCNT & $\mathrm{Cl}$ - channel 7 & $\mathrm{E}$ & IBID \\
\hline M & HMR & CLCNKA & $\mathrm{Cl}$ - channel $\mathrm{Ka}$ & $E$ & IBID \\
\hline
\end{tabular}

Calsequestrin 2

Cadherin 1, epithelial

Cadherin 10, type 2

(T2-cadherin)

Cadherin 11, osteoblast

Cadherin 15, M-cadherin (myotubule)

Cadherin 17, $\mathrm{LI}$ cadherin

(liver-intestine)

Cadherin 2, neuronal

Cadherin-like 23

Cadherin 5

Cadherin 6

Cystic fibrosis

transmembrane

conductance

regulator (ATP-binding

cassette subfamily $\mathrm{C}$,

member 7)

Cholinergic receptor (muscle)

c receptor

Cholinergic receptor

Cholinergic receptor

Cholinergic receptor

Cholinergic receptor

Cholinergic receptor

(cotinic, $\varepsilon$

olinergic receptor

$\mathrm{Ca}^{2+}$ and integrin

binding family

$\mathrm{Ca}^{2+}$-activated 3

Cl- channel

CLIC-like

Cl- channel 2

$\mathrm{Cl}$ - channel 3

Cl- channel 5

(nephrolithiasis

X-linked

$\mathrm{Cl}$ - channel 6

$\mathrm{Cl}-$ channel $\mathrm{Ka}$
C IBID

C $\quad$ IBID

C IBID

C IBID

C IBID

C IBID

C IBID

C IBID

C IBID

C IBID

E ATP-binding and phosphorylationdependent $\mathrm{Cl}$ - channel activity, channel-conductance-controlling ATPase activity

GO annotation 
TABLE 1 (continued)

Ion channel genes expressed in the inner ear as of March 2007

\begin{tabular}{|c|c|c|c|c|c|}
\hline Expressed & Genome & Gene symbol & Full name & $G O E$ & GO annotation \\
\hline MR & BDHMR & CLIC1 & $\begin{array}{l}\mathrm{Cl} \text { - intracellular } \\
\text { channel } 1\end{array}$ & $\mathrm{E}$ & $\begin{array}{l}\mathrm{Cl}-\text { channel activity, } \mathrm{Cl}_{v^{-}} \text {channel } \\
\text { activity }\end{array}$ \\
\hline $\mathrm{R}$ & $\mathrm{H}$ & CLIC2 & $\begin{array}{l}\mathrm{Cl} \text { - intracellular } \\
\text { channel } 2\end{array}$ & $\mathrm{C}$ & $\begin{array}{l}\mathrm{Cl}-\text { channel activity, } \mathrm{Cl}_{\mathrm{v}}-\text { channel } \\
\text { activity }\end{array}$ \\
\hline DHMR & BDHMR & CLIC4 & $\begin{array}{l}\mathrm{Cl} \text { intracellular } \\
\text { channel } 4\end{array}$ & $\mathrm{E}$ & $\mathrm{Cl}-$ channel activity \\
\hline $\mathrm{H}$ & BDHMR & CLIC5 & $\begin{array}{l}\mathrm{Cl} \text { intracellular } \\
\text { channel } 5\end{array}$ & $\mathrm{E}$ & $\begin{array}{l}\mathrm{Cl}-\text { channel activity, } \mathrm{Cl}_{\mathrm{v}}-\text { channel } \\
\text { activity }\end{array}$ \\
\hline Microarray & DHMR & CNGA2 & CNG channel $\alpha 2$ & $\mathrm{E}$ & $\mathrm{ICA}$ \\
\hline $\mathrm{D}$ & DR & CSEN & $\begin{array}{l}\text { Potassium channel- } \\
\text { interacting protein } \\
\text { KchIP }\end{array}$ & $\mathrm{E}$ & $\begin{array}{l}\mathrm{Ca}^{2+} \text { channel activity, } \mathrm{Ca}^{2+} \text { channel } \\
\text { inhibitor activity }\end{array}$ \\
\hline HM & HR & CUL5 & Cullin 5 & $\mathrm{E}$ & $\mathrm{Ca}^{2+}$ channel activity \\
\hline M & $\mathrm{BHM}$ & $C Y B B$ & $\begin{array}{l}\text { Cytochrome b- } 245 \text {, } \\
\text { beta polypeptide } \\
\text { (chronic granulomatous } \\
\text { disease) }\end{array}$ & $\mathrm{C}$ & $\begin{array}{l}\mathrm{Ca}^{2+} \text { channel regulator activity. } \\
\text { voltage-gated ICA }\end{array}$ \\
\hline $\mathrm{D}$ & $\mathrm{D}$ & $D L B$ & $\delta \mathrm{B}$ & $\mathrm{C}$ & $\begin{array}{l}\mathrm{Ca}^{2+} \text { channel activity, } \mathrm{Ca}^{2+} \text { channel } \\
\text { inhibitor activity }\end{array}$ \\
\hline MR & $\mathrm{D}$ & $D L D$ & $\delta \mathrm{D}$ & $\mathrm{E}$ & IBID \\
\hline $\mathrm{R}$ & $\mathrm{D}$ & EEF2K & $\begin{array}{l}\text { Elongation factor-2 } \\
\text { kinase }\end{array}$ & C & $\begin{array}{l}\mathrm{Ca}^{2+} \text { channel activity, } \mathrm{Ca}^{2+} \text { channel } \\
\text { inhibitor activity }\end{array}$ \\
\hline M & M & EG622320 & $\begin{array}{l}\text { Predicted gene, } \\
\text { EG622320 }\end{array}$ & $\mathrm{C}$ & $\begin{array}{l}\text { ICA, } K_{v} \text { channel activity, } K_{v} \text { channel } \\
\text { complex }\end{array}$ \\
\hline $\mathrm{H}$ & $\mathrm{D}$ & FAT & $\begin{array}{l}\text { FAT tumor suppressor } \\
\text { homolog } 1\end{array}$ & C & $\begin{array}{l}\mathrm{Ca}^{2+} \text { channel activity, } \mathrm{Ca}^{2+} \text { channel } \\
\text { inhibitor activity }\end{array}$ \\
\hline HMR & $\mathrm{D}$ & FBLN1 & Fibulin 1 & $\mathrm{C}$ & IBID \\
\hline $\mathrm{HM}$ & $\mathrm{R}$ & FGF2 & $\begin{array}{l}\text { Fibroblast growth } \\
\text { factor } 2\end{array}$ & $\mathrm{E}$ & $\mathrm{Ca}_{v}$ channel activity \\
\hline $\mathrm{R}$ & $\mathrm{D}$ & FKBP7 & FK506 binding protein 7 & $\mathrm{C}$ & $\begin{array}{l}\mathrm{Ca}^{2+} \text { channel activity, } \mathrm{Ca}^{2+} \text { channel } \\
\text { inhibitor activity }\end{array}$ \\
\hline DHMR & $\mathrm{D}$ & FKBP9 & FK506 binding protein 9 & C & IBID \\
\hline $\mathrm{HR}$ & $\mathrm{D}$ & FSTL5 & Follistatin-like 5 & C & IBID \\
\hline MR & HMR & FXYD1 & $\begin{array}{l}\text { FXYD domain containing } \\
\text { ion transport regulator } 1 \\
\text { (phospholemman) }\end{array}$ & $\mathrm{E}$ & $\mathrm{Cl}-$ channel activity, ICA \\
\hline $\mathrm{R}$ & BHMR & FXYD2 & $\begin{array}{l}\text { FXYD domain-containing } \\
\text { ion transport regulator } 2\end{array}$ & $\mathrm{E}$ & ICA \\
\hline $\mathrm{R}$ & $\mathrm{BHM}$ & FXYD3 & $\begin{array}{l}\text { FXYD domain containing } \\
\text { ion transport regulator } 3\end{array}$ & $\mathrm{E}$ & ICA \\
\hline MR & $\mathrm{HM}$ & FXYD5 & $\begin{array}{l}\text { FXYD domain-containing } \\
\text { ion transport regulator } 5\end{array}$ & $\mathrm{C}$ & ICA \\
\hline DHMR & $\mathrm{BHM}$ & FXYD6 & $\begin{array}{l}\text { FXYD domain containing } \\
\text { ion transport regulator } 6\end{array}$ & $\mathrm{C}$ & 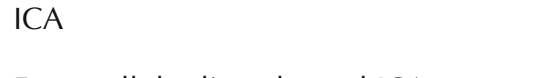 \\
\hline $\mathrm{R}$ & BGHMR & GABRA1 & $\begin{array}{l}\gamma \text {-aminobutyric acid } \\
(\text { GABA-A) receptor, } \alpha 1\end{array}$ & $\mathrm{E}$ & Extra-cellular ligand-gated ICA \\
\hline M & $\mathrm{BHM}$ & GABRA2 & GABA-A, $\alpha 2$ & C & IBID \\
\hline Microarray & $\mathrm{BHM}$ & GABRA3 & GABA-A, $\alpha 3$ & C & IBID \\
\hline Microarray & GHMR & GABRA6 & GABA-A, $\alpha 6$ & $\mathrm{E}$ & IBID \\
\hline Microarray & BGHMR & $G A B R B 1$ & GABA-A, $\beta 1$ & $\mathrm{E}$ & IBID \\
\hline Microarray & HMR & $G A B R B 2$ & GABA-A, $\beta 2$ & $\mathrm{E}$ & IBID \\
\hline Microarray & GHM & $G A B R B 3$ & GABA-A, $\beta 3$ & C & IBID \\
\hline Microarray & $\mathrm{HM}$ & $G A B R D$ & GABA-A, $\delta$ & C & IBID \\
\hline Microarray & BGHMR & GABRG2 & GABA-A, $\gamma 2$ & $\mathrm{E}$ & IBID \\
\hline Microarray & $\mathrm{HMR}$ & GABRG3 & GABA-A $\gamma 3$ & $\mathrm{E}$ & IBID \\
\hline Microarray & $\mathrm{HM}$ & $G A B R Q$ & GABA-A, $\theta$ & $\mathrm{E}$ & IBID \\
\hline Microarray & GHM & GABRR1 & GABA, $\rho 1$ & C & IBID \\
\hline Microarray & BGHMR & GABRR2 & GABA, $\rho 2$ & $\mathrm{E}$ & IBID \\
\hline DMR & BDHMR & GLRA3 & Glycine receptor, $\alpha 3$ & $\mathrm{E}$ & ICA, glycin-gated $\mathrm{Cl}-$ channel complex \\
\hline MR & BDHMR & $G L R B$ & Glycine receptor, $\beta$ & $\mathrm{E}$ & $\begin{array}{l}\text { Glycine-gated ICA, glycine-inhibited } \\
\mathrm{Cl}-\text { channel activity }\end{array}$ \\
\hline
\end{tabular}


TABLE 1 (continued)

Ion channel genes expressed in the inner ear as of March 2007

\begin{tabular}{|c|c|c|c|c|c|}
\hline Expressed & Genome & Gene symbol & Full name & $G O E$ & GO annotation \\
\hline$\overline{\mathrm{H}}$ & $\mathrm{D}$ & GPR98 & $\begin{array}{l}\text { G protein-coupled } \\
\text { receptor } 98\end{array}$ & $\mathrm{C}$ & $\begin{array}{l}\mathrm{ICA}, \mathrm{Ca}^{2+} \text { channel activity, } \mathrm{Ca}^{2+} \\
\text { channel inhibitor activity }\end{array}$ \\
\hline MR & DGHMR & GRIA2 & $\begin{array}{l}\text { Glutamate receptor, } \\
\text { ionotropic, AMPA2 }\end{array}$ & E & $\begin{array}{l}\text { ICA, glutamate-gated ICA, } \mathrm{K}^{+} \\
\text {channel activity }\end{array}$ \\
\hline DM & DGMH & GRIA3 & AMPA3 & E & Glutamate-gated ICA, ICA \\
\hline HMR & BDGHM & GRIA4 & AMPA4 & $\mathrm{C}$ & IBID \\
\hline $\mathrm{R}$ & $\mathrm{DHM}$ & GRID2 & $\begin{array}{l}\text { Glutamate receptor, } \\
\text { ionotropic, } \delta 2\end{array}$ & $\mathrm{E}$ & IBID \\
\hline HR & HMR & GRIK1 & $\begin{array}{l}\text { Glutamate receptor, } \\
\text { ionotropic, kainate } 1\end{array}$ & E & IBID \\
\hline $\mathrm{H}$ & HMR & GRIK2 & $\begin{array}{l}\text { Glutamate receptor, } \\
\text { ionotropic, kainate } 2\end{array}$ & E & IBID \\
\hline MR & GHMR & GRIN1 & $\begin{array}{l}\text { Glutamate receptor, } \\
\text { ionotropic, NMDA1 }\end{array}$ & E & $\begin{array}{l}\text { ICA, } \mathrm{K}^{+} \text {channel activity, } \\
\text { glutamate-gated ICA }\end{array}$ \\
\hline Microarray & & GRIN2A & $\begin{array}{l}\text { Glutamate receptor, } \\
\text { ionotropic, NMDA2A }\end{array}$ & E & ICA, glutamate-gated ICA, \\
\hline Microarray & HMR & GRIN2C & $\begin{array}{l}\text { Glutamate receptor, } \\
\text { ionotropic, NMDA2C }\end{array}$ & E & IBID \\
\hline M & HMR & GRIN2D & $\begin{array}{l}\text { Glutamate receptor, } \\
\text { ionotropic, NMDA2D }\end{array}$ & $\mathrm{E}$ & IBID \\
\hline $\mathrm{R}$ & $\mathrm{R}$ & GRINA & $\begin{array}{l}\text { Glutamate receptor, } \\
\text { ionotropic, NMDA- } \\
\text { associated }\end{array}$ & $\mathrm{C}$ & Cation channel activity \\
\hline Microarray & $\mathrm{D}$ & GUCA1A & $\begin{array}{l}\text { Guanylate cyclase } \\
\text { activator } 1 \mathrm{~A}\end{array}$ & $\mathrm{C}$ & $\begin{array}{l}\mathrm{Ca}^{2+} \text { channel activity, } \mathrm{Ca}^{2+} \text { channel } \\
\text { inhibitor activity }\end{array}$ \\
\hline MR & DM & HCN1 & $\begin{array}{l}\text { Hyperpolarization- } \\
\text { activated CNG K } \\
\text { channel }\end{array}$ & $\mathrm{C}$ & $\begin{array}{l}\mathrm{Na}^{+} \text {channel activity, } \mathrm{K}_{\mathrm{v}} \text { channel } \\
\text { activity }\end{array}$ \\
\hline M & $\mathrm{GHM}$ & HVCN1 & $\begin{array}{l}\text { Hydrogen voltage- } \\
\text { gated channel } 1\end{array}$ & E & $\begin{array}{l}\text { ICA, voltage-gated proton channel } \\
\text { activity }\end{array}$ \\
\hline $\mathrm{D}$ & $\mathrm{D}$ & $I C N$ & Ictacalcin & C & $\begin{array}{l}\mathrm{Ca}^{2+} \text { channel activity, } \mathrm{Ca}^{2+} \text { channel } \\
\text { inhibitor activity }\end{array}$ \\
\hline $\mathrm{HM}$ & BGHN & ITPR1 & $\begin{array}{l}\text { Inositol 1,4,5-triphosphate } \\
\text { receptor, type } 1\end{array}$ & E & $\mathrm{Ca}^{2+}$ channel activity \\
\hline MR & BHMR & ITPR2 & $\begin{array}{l}\text { Inositol 1,4,5-triphosphate } \\
\text { receptor, type } 2\end{array}$ & $E$ & $\begin{array}{l}\mathrm{Ca}^{2+} \text { channel activity, inositol 1,4,5- } \\
\text { triphosphate-sensitive } \mathrm{Ca}^{2+} \text {-release } \\
\text { channel activity, ICA }\end{array}$ \\
\hline Microarray & $\mathrm{BHM}$ & ITPR3 & $\begin{array}{l}\text { Inositol 1,4,5-triphosphate } \\
\text { receptor } 3\end{array}$ & E & IBID \\
\hline $\mathrm{HM}$ & $\mathrm{D}$ & ITSN1 & $\begin{array}{l}\text { Intersectin } 1 \text { (SH3 domain } \\
\text { protein) }\end{array}$ & C & $\begin{array}{l}\mathrm{Ca}^{2+} \text { channel activity, } \mathrm{Ca}^{2+} \text { channel } \\
\text { inhibitor activity }\end{array}$ \\
\hline DMR & $\mathrm{HM}$ & KCMF1 & $\begin{array}{l}\mathrm{K}^{+} \text {channel modulatory } \\
\text { factor } 1\end{array}$ & $\mathrm{C}$ & ICA \\
\hline MR & GHMR & KCNA1 & $\mathrm{K}_{\mathrm{v}}$, Shaker-related member 1 & $\mathrm{E}$ & $\mathrm{K}_{\mathrm{v}}$ channel activity/complex \\
\hline $\mathrm{HM}$ & GHMR & KCNA2 & $\mathrm{K}_{\mathrm{v}}$, Shaker-related member 2 & $\mathrm{E}$ & IBID \\
\hline Microarray & GHMR & KCNA3 & $\mathrm{K}_{\mathrm{v}}$, Shaker-related member 3 & $\mathrm{E}$ & IBID \\
\hline Microarray & BGHMR & KCNA4 & $\begin{array}{l}\mathrm{K}_{\mathrm{v}} \text { channel, Shaker-related } \\
\text { member } 4\end{array}$ & E & IBID \\
\hline Microarray & HMR & KCNA6 & $\begin{array}{l}\mathrm{K}_{\mathrm{v}} \text { channel, Shaker-related } \\
\text { member } 6\end{array}$ & $\mathrm{E}$ & IBID \\
\hline MR & GHMR & KCNA10 & $\begin{array}{l}\mathrm{K}_{\mathrm{v}} \text { channel, Shaker-related } \\
\text { member } 10\end{array}$ & E & IBID \\
\hline MR & BGHMR & KCNAB1 & $\mathrm{K}_{v}$ channel, Shaker-related $\beta 1$ & E & IBID \\
\hline M & BGHMR & KCNAB2 & $K_{v}$ channel, Shaker-related $\beta 2$ & $\mathrm{E}$ & IBID \\
\hline Microarray & HMR & KCNAB3 & $\mathrm{K}_{\mathrm{v}}$ channel, Shaker-related $\beta 3$ & $\mathrm{E}$ & IBID \\
\hline M & HMR & KCNB1 & $\begin{array}{l}\mathrm{K}_{\mathrm{v}} \text { channel, Shab-related } \\
\text { member } 1\end{array}$ & E & IBID \\
\hline M & $\mathrm{BHMR}$ & KCNB2 & $\begin{array}{l}\mathrm{K}_{\mathrm{v}} \text { channel, Shab-related } \\
\text { member } 2\end{array}$ & E & IBID \\
\hline $\mathrm{R}$ & BGHMR & KCNC1 & $\mathrm{K}_{\mathrm{v}}$ channel, Shaw-related & E & IBID \\
\hline
\end{tabular}


TABLE 1 (continued)

Ion channel genes expressed in the inner ear as of March 2007

\begin{tabular}{|c|c|c|c|c|c|}
\hline Expressed & Genome & Gene symbol & Full name & $G O E$ & GO annotation \\
\hline $\mathrm{R}$ & HMR & KCNC2 & $\begin{array}{l}\mathrm{K}_{\mathrm{v}} \text { channel, Shaw-related } \\
\text { member } 2\end{array}$ & $\mathrm{C}$ & IBID \\
\hline $\mathrm{R}$ & HMR & KCNC3 & $\begin{array}{l}\mathrm{K}_{\mathrm{v}} \text { channel, Shaw-related } \\
\text { member } 3\end{array}$ & $\mathrm{E}$ & IBID \\
\hline M & $\mathrm{HM}$ & KCNC4 & $\begin{array}{l}\mathrm{K}_{\mathrm{v}} \text { channel, Shaw-related } \\
\text { member } 4\end{array}$ & $\mathrm{E}$ & IBID \\
\hline Microarray & GHMR & KCND2 & $\begin{array}{l}\mathrm{K}_{\mathrm{v}} \text { channel, Shal-related } \\
\text { member } 2\end{array}$ & $E$ & IBID \\
\hline $\mathrm{R}$ & BHMR & KCNE1 & $\begin{array}{l}\mathrm{K}_{\mathrm{v}} \text { channel, Isk-related } \\
\text { family, member } 1\end{array}$ & E & IBID \\
\hline $\mathrm{H}$ & MHR & KCNG1 & $\begin{array}{l}\mathrm{K}_{\mathrm{v}} \text { channel, subfamily } \mathrm{G}, \\
\text { member } 1\end{array}$ & $\mathrm{C}$ & IBID \\
\hline $\mathrm{R}$ & BHMR & KCNH1 & $\begin{array}{l}\mathrm{K}_{\mathrm{v}} \text { channel, subfamily } \mathrm{H} \\
\text { (eag-related), member } 1\end{array}$ & E & IBID \\
\hline M & DHMR & $\mathrm{KCNH} 2$ & $\begin{array}{l}\mathrm{K}_{\mathrm{v}} \text { channel, subfamily } \mathrm{H} \\
\text { (eag-related), member } 2\end{array}$ & $E$ & IBID \\
\hline $\mathrm{HM}$ & HMR & KCNJ10 & $\mathrm{K}_{\mathrm{ir}}$, subfamily J, member 10 & $\mathrm{E}$ & ATP-activated $\mathrm{K}_{\mathrm{ir}}$ channel activity \\
\hline Microarray & DHMR & KCNJ11 & $\mathrm{K}_{\mathrm{ir}}$, subfamily J, member 11 & E & IBID \\
\hline Microarray & DHMR & KCNJ12 & $\mathrm{K}_{\mathrm{ir}}$, subfamily J, member 12 & E & IBID \\
\hline HMR & HMR & KCNJ16 & $\mathrm{K}_{\mathrm{ir}}$, subfamily J, member 16 & $\mathrm{C}$ & IBID \\
\hline $\mathrm{HM}$ & BGHM & KCNJ2 & $\begin{array}{l}\text { Kir channel, subfamily J, } \\
\text { member } 2\end{array}$ & $\mathrm{E}$ & IBID \\
\hline $\mathrm{R}$ & GHMR & KCNJ3 & $\begin{array}{l}\mathrm{K}_{\text {ir }} \text { channel, subfamily J, } \\
\text { member } 3\end{array}$ & $\mathrm{E}$ & $\begin{array}{l}\text { G-protein-activated } \mathrm{K}_{\text {ir }} \text { activity, } \\
\text { voltage-gated ICA }\end{array}$ \\
\hline Microarray & GHMR & KCNJ4 & $\begin{array}{l}\mathrm{K}_{\text {ir }} \text { channel, subfamily J, } \\
\text { member } 4\end{array}$ & $E$ & $\mathrm{~K}_{\mathrm{ir}}$ activity, $\mathrm{Kv}$ channel complex \\
\hline Microarray & GHMR & KCNJ5 & $\begin{array}{l}\mathrm{K}_{\text {ir }} \text { channel, subfamily J, } \\
\text { member } 5\end{array}$ & E & G-protein-activated $\mathrm{K}_{\mathrm{ir}}$ activity \\
\hline Microarray & HMR & KCNJ6 & $\begin{array}{l}\mathrm{K}_{\text {ir }} \text { channel, subfamily J, } \\
\text { member } 6\end{array}$ & $E$ & $\begin{array}{l}\text { G-protein-activated } \mathrm{K}_{\text {ir }} \text { activity, } \mathrm{K}_{\mathrm{v}} \\
\text { channel complex }\end{array}$ \\
\hline M & BDGHMR & KCNJ8 & $\begin{array}{l}\mathrm{K}_{\text {ir }} \text { channel, subfamily J, } \\
\text { member } 8\end{array}$ & $E$ & ATP-activated $\mathrm{K}_{\text {ir }}$ activity \\
\hline Microarray & HMR & KCNJ9 & $\begin{array}{l}\mathrm{K}_{\text {ir }} \text { channel, subfamily J, } \\
\text { member } 9\end{array}$ & $\mathrm{C}$ & G-protein activated $\mathrm{K}_{\mathrm{ir}}$ activity \\
\hline HMR & GHMR & KCNK1 & $\begin{array}{l}\mathrm{K}^{+} \text {channel, subfamily } \mathrm{K}, \\
\text { member } 1\end{array}$ & $\mathrm{E}$ & $\mathrm{K}^{+}$channel activity \\
\hline $\mathrm{H}$ & $\mathrm{BH}$ & KCNK17 & $\begin{array}{l}\mathrm{K}^{+} \text {channel, subfamily } \mathrm{K}, \\
\text { member } 17\end{array}$ & $\mathrm{E}$ & $\mathrm{K}^{+}$channel activity, voltage-gated ICA \\
\hline MR & BHMR & KCNK2 & $\begin{array}{l}\mathrm{K}^{+} \text {channel, subfamily } \mathrm{K}, \\
\text { member } 2\end{array}$ & $\mathrm{E}$ & ICA, $\mathrm{K}^{+}$channel activity \\
\hline M & $\mathrm{DHM}$ & KCNK5 & $\begin{array}{l}\mathrm{K}^{+} \text {channel, subfamily } \mathrm{K} \text {, } \\
\text { member } 5\end{array}$ & $\mathrm{E}$ & $\mathrm{K}^{+}$channel activity \\
\hline $\mathrm{D}$ & HMR & KCNK6 (TWK-6) & $\begin{array}{l}\mathrm{K}_{\text {ir }} \text { channel, subfamily } \mathrm{K}, \\
\text { member } 6\end{array}$ & $\mathrm{C}$ & $\begin{array}{l}\mathrm{K}_{\mathrm{ir}} \text { activity, } \mathrm{K}^{+} \text {channel activity, } \\
\text { voltage-gated ICA, } \mathrm{K}_{\mathrm{v}} \text { channel } \\
\text { complex }\end{array}$ \\
\hline DHMR & BGHMR & KCNMA1 & BK channel, subfamily $M, \alpha 1$ & E & ICA, $\mathrm{K}_{\mathrm{Ca}}$ activity, $\mathrm{K}_{\mathrm{v}}$ channel activity \\
\hline Microarray & & KCNMB1 & BK, subfamily $M, \beta 1$ & $\mathrm{E}$ & ICA, $\mathrm{K}_{\mathrm{Ca}}$ channel activity \\
\hline $\mathrm{H}$ & HMR & KCNMB2 & BK, subfamily $M, \beta 2$ & E & $\mathrm{K}^{+}$channel activity \\
\hline$R T-P C R$ & BHMR & KCNN1 & $\begin{array}{l}\text { IK/SK channel, subfamily N, } \\
\text { member } 1\end{array}$ & $\mathrm{E}$ & $\begin{array}{l}\text { SK channel activity, } K_{v} \text { channel } \\
\text { complex }\end{array}$ \\
\hline$R T-P C R$ & BGHMR & KCNN2 & IK/SK channel, member 2 & E & SK channel activity \\
\hline $\mathrm{R}$ & HMR & KCNN4 & IK/SK channel, member 4 & $\mathrm{E}$ & IK/SK channel activity \\
\hline $\mathrm{HM}$ & HMR & $K C N Q 1$ & $\begin{array}{l}\mathrm{K}_{\mathrm{v}} \text { channel, KQT-like } \\
\text { subfamily, member } 1\end{array}$ & $\mathrm{E}$ & $\begin{array}{l}\mathrm{K}_{v} \text { channel activity, } \mathrm{K}_{\mathrm{v}} \text { channel } \\
\text { complex }\end{array}$ \\
\hline$R T-P C R$ & HMR & KCNQ2 & $\begin{array}{l}\mathrm{K}_{\mathrm{v}} \text { channel, subfamily } \mathrm{Q}, \\
\text { member } 2\end{array}$ & $E$ & IBID \\
\hline$R T-P C R$ & BHMR & KCNQ3 & $\begin{array}{l}\mathrm{K}_{\mathrm{v}} \text { channel, subfamily } \mathrm{Q}, \\
\text { member } 3\end{array}$ & $E$ & IBID \\
\hline$M$ & GHMR & KCNQ4 & $\begin{array}{l}\mathrm{K}_{\mathrm{v}} \text { channel, subfamily } \mathrm{Q}, \\
\text { member } 4\end{array}$ & $E$ & IBID \\
\hline
\end{tabular}


TABLE 1 (continued)

Ion channel genes expressed in the inner ear as of March 2007

\begin{tabular}{|c|c|c|c|c|c|}
\hline Expressed & Genome & Gene symbol & Full name & $G O E$ & GO annotation \\
\hline DM & $\mathrm{HMR}$ & KCNQ5 & $\begin{array}{l}\mathrm{K}_{\mathrm{v}} \text { channel, subfamily } \mathrm{Q}, \\
\text { member } 5\end{array}$ & E & IBID \\
\hline $\mathrm{R}$ & HMR & KCNS1 & $\begin{array}{l}\mathrm{K}_{\mathrm{v}} \text { channel, delayed } \\
\text { rectifier, subfamily } \mathrm{S}, \\
\text { member } 1\end{array}$ & $\mathrm{E}$ & $\begin{array}{l}\mathrm{K}^{+} \text {channel regulator activity, } \mathrm{K}_{\mathrm{v}} \\
\text { channel complex }\end{array}$ \\
\hline Microarray & $\mathrm{HM}$ & KCNS2 & $\begin{array}{l}\mathrm{K}_{\mathrm{v}} \text { channel, delayed-rectifier, } \\
\text { subfamily } \mathrm{S} \text {, member } 2\end{array}$ & C & IBID \\
\hline MR & GHMR & KCNT1 & $\begin{array}{l}\mathrm{K}^{+} \text {channel, subfamily } \mathrm{T} \\
\text { member } 1\end{array}$ & E & $\begin{array}{l}\mathrm{K}_{\mathrm{Ca}} \text { and } \mathrm{K}^{+} \text {channel activity, } \\
\text { voltage-gated ICA }\end{array}$ \\
\hline $\mathrm{R}$ & BGHM & KCTD1 & $\begin{array}{l}\mathrm{K}^{+} \text {channel tetramerization } \\
\text { domain containing } 1\end{array}$ & $\mathrm{C}$ & $\mathrm{K}_{\mathrm{v}}$ channel activity/complex \\
\hline $\mathrm{HR}$ & BDHMR & KCTD10 & $\begin{array}{l}\mathrm{K}^{+} \text {channel tetramerization } \\
\text { domain containing } 10\end{array}$ & $\mathrm{C}$ & IBID \\
\hline M & $\mathrm{BHM}$ & KCTD11 & $\begin{array}{l}\mathrm{K}^{+} \text {channel tetramerization } \\
\text { domain containing } 11\end{array}$ & $\mathrm{C}$ & IBID \\
\hline HMR & $\mathrm{DHM}$ & KCTD12 & $\begin{array}{l}\mathrm{K}^{+} \text {channel tetramerization } \\
\text { domain containing } 12\end{array}$ & $\mathrm{C}$ & IBID \\
\hline $\mathrm{H}$ & HMR & КСTD13 & $\begin{array}{l}\mathrm{K}^{+} \text {channel tetramerization } \\
\text { domain containing } 13\end{array}$ & $\mathrm{C}$ & IBID \\
\hline $\mathrm{R}$ & GHM & KCTD14 & $\begin{array}{l}\mathrm{K}^{+} \text {channel tetramerization } \\
\text { domain containing } 14\end{array}$ & $\mathrm{C}$ & IBID \\
\hline MR & $\mathrm{BHM}$ & КСTD15 & $\begin{array}{l}\mathrm{K}^{+} \text {channel tetramerization } \\
\text { domain containing } 15\end{array}$ & C & IBID \\
\hline M & GHM & KCTD17 & $\begin{array}{l}\mathrm{K}^{+} \text {channel tetramerization } \\
\text { domain containing } 17\end{array}$ & C & IBID \\
\hline M & HMR & КCTD3 & $\begin{array}{l}\mathrm{K}^{+} \text {channel tetramerization } \\
\text { domain containing } 3\end{array}$ & $\mathrm{C}$ & IBID \\
\hline M & HMR & КСTD5 & $\begin{array}{l}\mathrm{K}^{+} \text {channel tetramerization } \\
\text { domain containing } 5\end{array}$ & C & IBID \\
\hline $\mathrm{HR}$ & $\mathrm{DHM}$ & КСTD6 & $\begin{array}{l}\mathrm{K}^{+} \text {channel tetramerization } \\
\text { domain containing } 6\end{array}$ & C & IBID \\
\hline $\mathrm{H}$ & $\mathrm{DHM}$ & КСTD7 & $\begin{array}{l}\mathrm{K}^{+} \text {channel tetramerization } \\
\text { domain containing } 7\end{array}$ & $\mathrm{C}$ & IBID \\
\hline$R$ & $\mathrm{DHM}$ & КCTD8 & $\begin{array}{l}\mathrm{K}^{+} \text {channel tetramerization } \\
\text { domain containing } 8\end{array}$ & $\mathrm{C}$ & IBID \\
\hline MR & DGHM & KCTD9 & $\begin{array}{l}\mathrm{K}^{+} \text {channel tetramerization } \\
\text { domain containing } 9\end{array}$ & $\mathrm{C}$ & IBID \\
\hline $\mathrm{R}$ & M & KLHL24 & Kelch-like 24 (Drosophila) & C & ICA \\
\hline MR & $\mathrm{D}$ & $L C P 1$ & $\begin{array}{l}\text { Lymphocyte cytosolic } \\
\text { plastin } 1\end{array}$ & $\mathrm{C}$ & $\begin{array}{l}\mathrm{Ca}^{2+} \text { channel activity, } \mathrm{Ca}^{2+} \text { channel } \\
\text { inhibitor activity, }\end{array}$ \\
\hline $\mathrm{H}$ & $\mathrm{H}$ & LOC729317 & $\begin{array}{l}\text { Similar to voltage-dependent } \\
\text { anion channel } 2\end{array}$ & C & $\begin{array}{l}\text { Voltage-gated ion-selective channel } \\
\text { activity }\end{array}$ \\
\hline DHMR & $\mathrm{D}$ & MAT2A & $\begin{array}{l}\text { Methionine } \\
\text { adenosyltransferase II, } \alpha\end{array}$ & $\mathrm{C}$ & $\begin{array}{l}\text { ICA, } \mathrm{K}^{+} \text {channel activity, } \mathrm{K}^{+} \text {channel } \\
\text { inhibitor activity }\end{array}$ \\
\hline $\mathrm{R}$ & $\mathrm{D}$ & MCFD2 & $\begin{array}{l}\text { Multiple coagulation } \\
\text { factor deficiency } 2\end{array}$ & $\mathrm{C}$ & $\begin{array}{l}\mathrm{Ca}^{2+} \text { channel activity, } \mathrm{Ca}^{2+} \text { channel } \\
\text { inhibitor activity }\end{array}$ \\
\hline HMR & GHMR & MCOLN1 & Mucolipin 1 & $\mathrm{C}$ & $\begin{array}{l}\mathrm{K}^{+} \text {channel activity, cation } \\
\text { channel activity }\end{array}$ \\
\hline Microarray & DHMR & MCOLN2 & Mucolipin 2 & $\mathrm{C}$ & ICA \\
\hline RT-PCR & DHMR & MCOLN3 & Mucolipin 3 & C & ICA \\
\hline Microarray & $\mathrm{HR}$ & MS4A2 & $\begin{array}{l}\text { Membrane-spanning } \\
\text { 4-domains, subfamily } \\
\text { A, member } 2\end{array}$ & $\mathrm{E}$ & $\mathrm{Ca}^{2+}$ channel activity \\
\hline Microarray & $\mathrm{D}$ & $M Y L 7$ & $\begin{array}{l}\text { Myosin, light polypeptide } 7 \text {, } \\
\text { regulatory }\end{array}$ & $\mathrm{C}$ & $\begin{array}{l}\mathrm{Ca}^{2+} \text { channel activity, } \mathrm{Ca}^{2+} \text { channel } \\
\text { inhibitor activity }\end{array}$ \\
\hline Microarray & $\mathrm{D}$ & MYL9 & $\begin{array}{l}\text { Myosin, light polypeptide } 9, \\
\text { regulatory }\end{array}$ & $\mathrm{C}$ & IBID \\
\hline $\mathrm{R}$ & $\mathrm{R}$ & NID67 & $\begin{array}{l}\text { Putative small membrane } \\
\text { protein NID67 }\end{array}$ & $\mathrm{C}$ & ICA \\
\hline
\end{tabular}


TABLE 1 (continued)

Ion channel genes expressed in the inner ear as of March 2007

\begin{tabular}{|c|c|c|c|c|c|}
\hline Expressed & Genome & Gene symbol & Full name & $G O E$ & GO annotation \\
\hline M & $M$ & NUDT9 & $\begin{array}{l}\text { Nudix (nucleoside } \\
\text { diphosphate linked } \\
\text { moiety X)-type motif } 9\end{array}$ & $\mathrm{C}$ & $\mathrm{Ca}^{2+}$-activated cation channel activity \\
\hline MR & DHMR & $P 2 R X 2$ & $\begin{array}{l}\text { Purinergic receptor } \mathrm{P} 2 \mathrm{X} \\
\text { ligand-gated ion channel, } 2\end{array}$ & $\mathrm{E}$ & $\begin{array}{l}\mathrm{Ca}^{2+} \text { channel regulator activity, } \\
\text { ligand-gated ICA }\end{array}$ \\
\hline DM & DHMR & $P 2 R X 3$ & $\begin{array}{l}\text { Purinergic receptor P2X, } \\
\text { ligand-gated ion channel, } 3\end{array}$ & $\mathrm{E}$ & ATP-gated cation channel activity \\
\hline MR & BDHMR & $P 2 R X 7$ & $\begin{array}{l}\text { Purinergic receptor P2X, } \\
\text { ligand-gated ion channel, } 7\end{array}$ & $\mathrm{E}$ & ICA \\
\hline $\mathrm{R}$ & $\mathrm{HMR}$ & $P 2 R X L 1$ & $\begin{array}{l}\text { Purinergic receptor } \\
\text { P2X-like } 1 \text {, orphan receptor }\end{array}$ & $\mathrm{E}$ & ICA \\
\hline HMR & HMR & PKD1 & $\begin{array}{l}\text { Polycystic kidney disease } \\
1 \text { homolog }\end{array}$ & $\mathrm{E}$ & $\begin{array}{l}\mathrm{Ca}^{2+} \text { channel activity, cation channel } \\
\text { activity }\end{array}$ \\
\hline Microarray & $\mathrm{H}$ & PKD1L3 & $\begin{array}{l}\text { Polycystic kidney disease } \\
\text { 1-like } 3\end{array}$ & $\mathrm{C}$ & ICA \\
\hline $\mathrm{HM}$ & BDHM & PKD2 & $\begin{array}{l}\text { Polycystic kidney disease } \\
\text { gene- } 2\end{array}$ & $\mathrm{E}$ & $\begin{array}{l}\text { Ca channel activity, IMP cation } \\
\text { channel activity }\end{array}$ \\
\hline RT-PCR & $\mathrm{HM}$ & PKD2L1 & PKD2-like 1 & C & ICA \\
\hline $\mathrm{R}$ & HMR & $P L L P$ & $\begin{array}{l}\text { Plasma membrane } \\
\text { proteolipid }\end{array}$ & $\mathrm{C}$ & ICA \\
\hline DR & $\mathrm{D}$ & POLB & $\begin{array}{l}\text { Polymerase (DNA } \\
\text { directed), } \beta\end{array}$ & C & $\begin{array}{l}\mathrm{Na}^{+} \text {channel activity, } \mathrm{Na}^{+} \text {channel } \\
\text { inhibitor activity }\end{array}$ \\
\hline M & $\mathrm{D}$ & RCN3 & $\begin{array}{l}\text { Reticulocalbin 3, } \\
\text { EF-hand Ca binding } \\
\text { domain }\end{array}$ & $\mathrm{C}$ & $\begin{array}{l}\mathrm{Ca}^{2+} \text { channel activity, } \mathrm{Ca}^{2+} \text { channel } \\
\text { inhibitor activity }\end{array}$ \\
\hline $\mathrm{H}$ & $\mathrm{D}$ & RHOT1 & $\begin{array}{l}\text { Ras homolog gene } \\
\text { family, member T1 }\end{array}$ & $\mathrm{C}$ & IBID \\
\hline $\mathrm{R}$ & GHMR & $R Y R 1$ & $\begin{array}{l}\text { Ryanodine receptor } 1 \\
\text { (skeletal) }\end{array}$ & $\mathrm{E}$ & $\begin{array}{l}\text { ICA, ryanodine-sensitive } \mathrm{Ca}^{2+} \text {-release } \\
\text { channel activity, } \mathrm{Ca}_{\mathrm{v}} \text { channel activity }\end{array}$ \\
\hline $\mathrm{H}$ & $\mathrm{HM}$ & RYR2 & $\begin{array}{l}\text { Ryanodine receptor } 2 \\
\text { (cardiac) }\end{array}$ & $\mathrm{E}$ & $\begin{array}{l}\text { ICA, ryanodine-sensitive } \mathrm{Ca}^{2+} \text {-release } \\
\text { channel activity, }\end{array}$ \\
\hline $\mathrm{R}$ & GHM & RYR3 & Ryanodine receptor 3 & $\mathrm{E}$ & IBID \\
\hline M & HMR & SCN10A & $\mathrm{Na}_{\mathrm{v}}$, type $\mathrm{X}, \alpha$ & $\mathrm{E}$ & ICA, $\mathrm{Na}_{v}$ channel activity/complex \\
\hline $\mathrm{R}$ & DGHMR & SCN1A & $\mathrm{Na}_{\mathrm{v}}$, type I, $\alpha$ & $\mathrm{E}$ & IBID \\
\hline Microarray & $\mathrm{HM}$ & SCN1B & $\mathrm{Na}_{\mathrm{v}}$, type I, $\beta$ & $\mathrm{E}$ & IBID \\
\hline$R T-P C R$ & $\mathrm{DH}$ & $S C N 2 A$ & $\mathrm{Na}_{\mathrm{v}}$, type II, $\alpha$ & $\mathrm{E}$ & IBID \\
\hline $\mathrm{H}$ & $\mathrm{HMR}$ & $S C N 3 A$ & $\mathrm{Na}_{\mathrm{v}}$, type III, $\alpha$ & $\mathrm{E}$ & IBID \\
\hline MR & BHMR & $S C N 4 B$ & $\mathrm{Na}_{\mathrm{V}}$, type IV, $\beta$ & $\mathrm{E}$ & IBID \\
\hline RT-PCR & BGHMR & SCN $5 A$ & $\mathrm{Na}_{\mathrm{V}}$, type $\mathrm{V}, \alpha$ & $\mathrm{E}$ & IBID \\
\hline $\mathrm{HR}$ & HMR & $S C N 7 A$ & $\mathrm{Na}_{\mathrm{v}}$, type VII, $\alpha$ & $\mathrm{E}$ & IBID \\
\hline D & $\mathrm{D}$ & SCNBAA & $\mathrm{Na}_{\mathrm{V}}$, type VIII, $\alpha$ & $\mathrm{E}$ & IBID \\
\hline Microarray & DHMR & SCN9A & $\mathrm{Na}_{\mathrm{v}}$, type IX, $\alpha$ & $\mathrm{E}$ & IBID \\
\hline M & HMR & SCNN1B & $\begin{array}{l}\mathrm{Na}^{+} \text {channel, } \\
\text { nonvoltage-gated } \beta 1\end{array}$ & $\mathrm{E}$ & $\begin{array}{l}\text { Amiloride-sensitive } \mathrm{Na}^{+} \text {channel } \\
\text { activity }\end{array}$ \\
\hline M & $\mathrm{HM}$ & SHKBP1 & $\begin{array}{l}\text { Sh3kbp1 binding } \\
\text { protein } 1\end{array}$ & C & $\mathrm{K}_{\mathrm{v}}$ channel activity/complex \\
\hline HMR & $\mathrm{D}$ & SLC25A12 & $\begin{array}{l}\text { solute carrier family } \\
25 \text { (mitochondrial } \\
\text { carrier, Aralar), member }\end{array}$ & C & $\begin{array}{l}\mathrm{Ca}^{2+} \text { channel activity, } \mathrm{Ca}^{2+} \text { channel } \\
\text { inhibitor activity }\end{array}$ \\
\hline MR & $M R$ & SLC9A1 & $\begin{array}{l}\text { Solute carrier family } 9 \text {, } \\
\text { member } 1\end{array}$ & $\mathrm{E}$ & ICA \\
\hline$M$ & $M R$ & SLC9A2 & $\begin{array}{l}\text { Solute carrier family } 9, \\
\mathrm{Na}^{+} / \mathrm{H}^{+} \text {exchanger, } \\
\text { member } 2\end{array}$ & $\mathrm{E}$ & ICA \\
\hline DHMR & $\mathrm{R}$ & SNAP25 & $\begin{array}{l}\text { Synaptosomal-associated } \\
\text { protein } 25\end{array}$ & $\mathrm{E}$ & $\mathrm{K}_{\mathrm{v}}$ channel activity/complex \\
\hline Microarray & $\mathrm{D}$ & SPARC & $\begin{array}{l}\text { Secreted acidic cysteine } \\
\text { rich glycoprotein }\end{array}$ & $\mathrm{C}$ & $\begin{array}{l}\mathrm{Ca}^{2+} \text { channel activity, } \mathrm{Ca}^{2+} \text { channel } \\
\text { inhibitor activity }\end{array}$ \\
\hline Microarray & $\mathrm{DHM}$ & STIM1 & $\begin{array}{l}\text { Stromal interaction } \\
\text { molecule } 1\end{array}$ & $\mathrm{E}$ & $\begin{array}{l}\mathrm{K}_{\mathrm{v}} \text { channel activity, activation of } \\
\text { store-operated } \mathrm{Ca}^{2+} \text { channel activity }\end{array}$ \\
\hline
\end{tabular}


TABLE 1 (continued)

Ion channel genes expressed in the inner ear as of March 2007

\begin{tabular}{|c|c|c|c|c|c|}
\hline Expressed & Genome & Gene symbol & Full name & $G O E$ & GO annotation \\
\hline Microarray & $\mathrm{H}$ & $S T X 1 B 1$ & Syntaxin 1B1 & E & $\begin{array}{l}\text { Extracellular ligand-gated ICA, } \\
\text { glutamate-gated ICA }\end{array}$ \\
\hline DHMR & $\mathrm{H}$ & TAX1BP3 & $\begin{array}{l}\text { Tax1 (human T-cell } \\
\text { leukemia virus type I) } \\
\text { binding protein } 3\end{array}$ & $\mathrm{E}$ & ICA \\
\hline $\mathrm{D}$ & $\mathrm{D}$ & TCTP & $\begin{array}{l}\text { Translationally controlled } \\
\text { tumor protein }\end{array}$ & $\mathrm{C}$ & $\begin{array}{l}\mathrm{Ca}^{2+} \text { channel activity, } \mathrm{Ca}^{2+} \text { channel } \\
\text { inhibitor activity }\end{array}$ \\
\hline $\mathrm{H}$ & $\mathrm{D}$ & TLL1 & Tolloid-like 1 & E & $\begin{array}{l}\text { ICA, } \mathrm{Ca}^{2+} \text { channel activity, } \mathrm{Ca}^{2+} \\
\text { channel inhibitor activity }\end{array}$ \\
\hline DM & HMR & TMEM37 & Transmembrane protein 37 & $\mathrm{C}$ & $\mathrm{Ca}_{v}$ channel activity/complex \\
\hline $\mathrm{HM}$ & DGHMR & TNFAIP1 & $\begin{array}{l}\text { Tumor necrosis factor, } \\
\alpha \text {-induced protein } 1 \\
\text { (endothelial) }\end{array}$ & $\mathrm{C}$ & $\mathrm{K}_{\mathrm{v}}$ channel activity/complex \\
\hline $\mathrm{D}$ & DHMR & TNNC1 & Troponin C, slow & C & $\begin{array}{l}\mathrm{Ca}^{2+} \text { channel activity, } \mathrm{Ca}^{2+} \text { channel } \\
\text { inhibitor activity }\end{array}$ \\
\hline DM & $\mathrm{BDHM}$ & TOMM40 & $\begin{array}{l}\text { Translocase of outer } \\
\text { mitochondrial membrane } \\
40 \text { homolog (yeast) }\end{array}$ & $\mathrm{C}$ & $\begin{array}{l}\text { Voltage-gated ion-selective channel } \\
\text { activity }\end{array}$ \\
\hline MR & HMR & TPCN1 & $\begin{array}{l}\text { Two pore segment } \\
\text { channel } 1\end{array}$ & $\mathrm{C}$ & $\begin{array}{l}\mathrm{Ca}^{2+} \text { channel activity, voltage-gated } \\
\mathrm{ICA}\end{array}$ \\
\hline DHM & DHMR & TRPA1 & $\begin{array}{l}\text { Transient receptor } \\
\text { potential A1 }\end{array}$ & E & $\mathrm{Ca}^{2+}$ channel activity, ICA \\
\hline MR & BGHMR & TRPC1 & $\begin{array}{l}\text { Transient receptor } \\
\text { potential cation channel, } \\
\text { subfamily C, member } 1\end{array}$ & $\mathrm{E}$ & $\begin{array}{l}\text { Store-operated } \mathrm{Ca}^{2+} \text { channel activity, } \\
\mathrm{Ca}^{2+} \text { channel activity, ICA }\end{array}$ \\
\hline RT-PCR & BM & TRPC2 & TRPC, member 2 & C & IBID \\
\hline $\mathrm{R}$ & $\mathrm{BHMR}$ & TRPC3 & $\begin{array}{l}\text { transient receptor } \\
\text { potential cation channel, } \\
\text { subfamily C, member } 3\end{array}$ & $\mathrm{E}$ & IBID \\
\hline $\mathrm{R}$ & BHMR & TRPC4 & $\begin{array}{l}\text { Transient receptor potential } \\
\text { cation channel, subfamily } \\
\text { C, member } 4\end{array}$ & E & IBID \\
\hline MPSS & $\mathrm{HM}$ & TRPM1 & $\begin{array}{l}\text { Transient receptor potential } \\
\text { cation channel, subfamily } \\
\text { M, member } 1\end{array}$ & E & $\mathrm{ICA}$ \\
\hline HMR & HM & TRPM3 & $\begin{array}{l}\text { Transient receptor potential } \\
\text { cation channel, subfamily } \\
\text { M, member } 3\end{array}$ & $\mathrm{C}$ & $\mathrm{Ca}^{2+}$ channel activity, ICA \\
\hline M & HMR & TRPM4 & $\begin{array}{l}\text { Transient receptor potential } \\
\text { cation channel, subfamily } \\
\text { M, member } 4\end{array}$ & $\mathrm{E}$ & $\begin{array}{l}\mathrm{Ca}^{2+} \text { channel activity, cation channel } \\
\text { activity, ICA }\end{array}$ \\
\hline RT-PCR & HMR & TRPMS & TRPM, member 5 & $\mathrm{C}$ & IBID \\
\hline $\mathrm{HM}$ & DHMR & TRPMT & $\begin{array}{l}\text { Transient receptor potential- } \\
\text { related protein, ChaK }\end{array}$ & $\mathrm{E}$ & $\begin{array}{l}\mathrm{Ca}^{2+} \text { channel activity, cation channel } \\
\text { activity }\end{array}$ \\
\hline$R T-P C R$ & DHMR & TRPV1 & $\begin{array}{l}\text { Transient receptor potential } \\
\text { cation channel, subfamily } \\
\text { V, member } 1\end{array}$ & E & Ion channel activity \\
\hline MPSS & BHMR & TRPV2 & $\begin{array}{l}\text { Transient receptor potential } \\
\text { cation channel, subfamily } \\
\text { V, member } 2\end{array}$ & E & ICA \\
\hline M & GHMR & TRPV4 & $\begin{array}{l}\text { Transient receptor potential } \\
\text { cation channel, subfamily } \\
\text { V, member } 4\end{array}$ & E & $\mathrm{ICA}$ \\
\hline MPSS & DHMR & TRPV6 & $\begin{array}{l}\text { Transient receptor potential } \\
\text { cation channel, subfamily } \\
\text { V, member } 6\end{array}$ & E & ICA \\
\hline $\mathrm{R}$ & M & TTYH3 & $\begin{array}{l}\text { Tweety homolog } 3 \\
\text { (Drosophila) }\end{array}$ & $E$ & ICA, Cl- channel activity \\
\hline HMR & BGHMR & VDAC1 & $\begin{array}{l}\text { Voltage-dependent } \\
\text { anion channel } 1\end{array}$ & $\mathrm{C}$ & $\begin{array}{l}\text { Voltage-gated ion-selective } \\
\text { channel/porin activity }\end{array}$ \\
\hline
\end{tabular}


TABLE 1 (continued)

Ion channel genes expressed in the inner ear as of March 2007

\begin{tabular}{|c|c|c|c|c|c|}
\hline Expressed & Genome & Gene symbol & Full name & $G O E$ & GO annotation \\
\hline $\mathrm{HM}$ & BDGHMR & VDAC2 & $\begin{array}{l}\text { Voltage-dependent } \\
\text { anion channel } 2\end{array}$ & $E$ & IBID \\
\hline$M R$ & BGHMR & VDAC3 & $\begin{array}{l}\text { Voltage-dependent } \\
\text { anion channel } 3\end{array}$ & $\mathrm{E}$ & $\begin{array}{l}\text { Voltage-gated anion channel } \\
\text { porin activity }\end{array}$ \\
\hline DMR & HMR & VGCNL1 & $\begin{array}{l}\text { Voltage-gated } \\
\text { channel like } 1\end{array}$ & $\mathrm{E}$ & IBID \\
\hline $\mathrm{D}$ & $\mathrm{D}$ & zgc:110679 & zgc:110679 & $\mathrm{C}$ & $\begin{array}{l}\mathrm{Ca}^{2+} \text { channel activity, } \mathrm{Ca}^{2+} \text { channel } \\
\text { inhibitor activity }\end{array}$ \\
\hline $\mathrm{D}$ & $\mathrm{D}$ & zgc:110771 & zgc:110771 & C & IBID \\
\hline $\mathrm{D}$ & $\mathrm{D}$ & $z g c: 123271$ & zgc:123271 & $\mathrm{C}$ & $\mathrm{K}^{+}$channel activity \\
\hline $\mathrm{D}$ & $\mathrm{D}$ & zgc:91851 & zgc:91851 & $\mathrm{C}$ & $\begin{array}{l}\mathrm{Ca}^{2+} \text { channel activity, } \mathrm{Ca}^{2+} \text { channel } \\
\text { inhibitor activity }\end{array}$ \\
\hline $\mathrm{D}$ & $\mathrm{D}$ & zgc:92169 & zgc:92169 & $\mathrm{C}$ & IBID \\
\hline HMR & $\mathrm{H}$ & ZIC2 & $\begin{array}{l}\text { Zic family member 2, } \\
\text { odd-paired homolog, } \\
\text { Drosophila }\end{array}$ & $\mathrm{C}$ & $\mathrm{K}_{\mathrm{v}}$ channel activity/complex \\
\hline
\end{tabular}

Ion channel transcripts presented in column 1 were initially identified in cDNA libraries made from human cochlea (H), mouse organ of Corti and mouse inner ear (M), rat vestibule (R), and zebrafish inner ear (D). Additional transcripts included were identified in mouse and rat microarrays, by MPSS of mouse inner ear, and by RT-PCR experiments. The Genome column presents the organisms whose genomic profiles were screened and found to contain specific genes annotated as having ion channel activity; the GOE column stands for Gene Ontology Evidence, with $\mathrm{E}$ and $\mathrm{C}$ referring to experimental and computational evidence, respectively; the GO Annotation column presents channel-related gene ontology annotations. We note that GO annotations are sometimes contradicted by experimental evidence. B Bos taurus, D Danio rerio, G Gallus gallus, H Homo sapiens, M Mus musculus, $R$ Rattus norvegicus, ICA ion channel activity, IBID the same.

and supplementary materials along with their GenBank accession number or sequence.

\section{Ion channel isoforms of the inner ear}

Table 2 lists ion channel transcripts identified in both the human fetal cochlear and mouse organ of Corti libraries using our EST mapping technique. Almost half of the voltage-gated and mechanosensitive ion channels are represented as splice variants not yet annotated in either human or mouse genome builds. Some of these variants are annotated as putative genes by UniGene. For example, novel TRPM3 ESTs available in GenBank are grouped in the Mm.131943 UniGene cluster, along with known isoforms of this gene, although, novel human ESTs belong to the Hs.50319 cluster annotated as "transcribed locus, cDNA DKFZp761C1418". However, neither of the mouse or human novel TRPM3 ESTs (Fig. 4a) was annotated in the UCSC genome browser, latest NCBI builds of human and mouse genomes, or SWISS-PROT, TrEMBL, GenBank mRNA, or RefSeq. Many cDNA library artifacts could potentially lead to identification of nonexisting splice variants. Thus, our confidence in novel isoforms is based on multiple EST-EST and organism-to-organism alignments. Thirty-seven human cochlear ESTs (28 unique clones) and 30 mouse clones are aligned to unannotated regions downstream of ion channel genes in human and mouse genomes. Among these novel transcripts, all novel isoforms identified by us correspond to novel or known isoforms of another organism (human cochlea vs mouse organ of Corti) (Fig. 4a-d). For several genes, an unannotated gene variant in mouse aligns to a known or predicted variant in humans (Fig. 4c,d, others not shown). For several other genes, an unannotated human gene variant aligns to a known mouse gene (Fig. 4b, others not shown). In addition, we have identified shorter than currently annotated versions of genes, such as those of KCTD12/Kctd12 (not shown) and KCNMA1 (Figs. 3, 4c). All ion channel genes listed in Table 2 are expressed also in the brain and other organs. Ion channel genes identified in the inner ear from the cDNA libraries analyzed are listed in the supplementary materials along with their GenBank accession number or sequence.

\section{Detection and characterization of expression of computationally predicted ion channel gene candidates}

RT-PCR experiments using RNA derived from various mouse tissues, including inner ear, confirm the expression of some of the predicted "novel" gene isoforms listed in Table 2. Expression of Otor (otoraplin) illustrates cochlear-specific expression of a gene for comparison, while equivalent expression levels of Gapdh were observed in all tissues, in agreement with statistical analysis of EST libraries (see Supplementary Material). Figure 3 illustrates that for both Trpm3 and Kcna2, transcripts of both the previously reported "known" isoforms and the newly identified longer isoforms are present in 


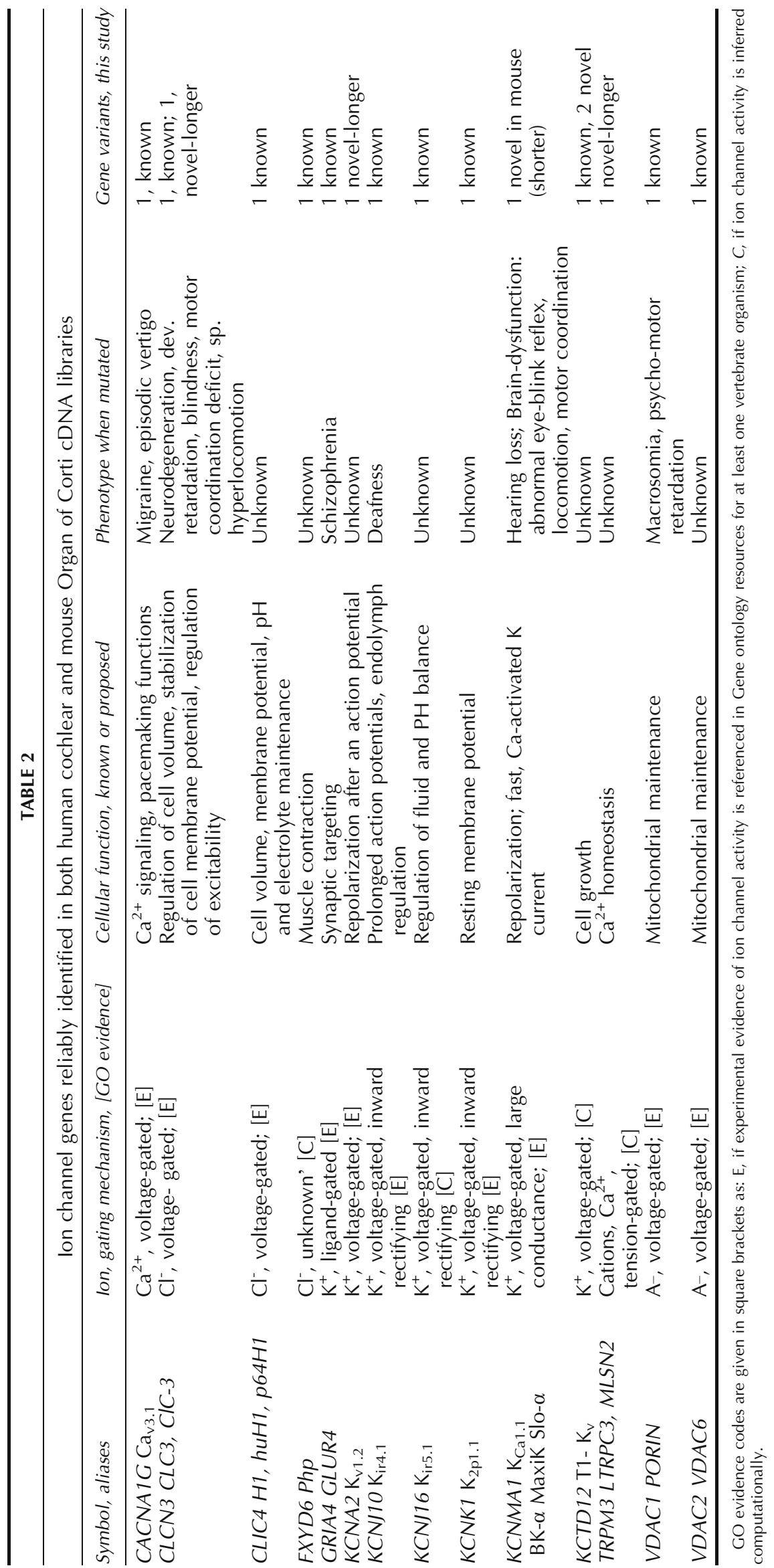


mouse brain and cochlea, despite the fact that in the EST-based analysis of transcript frequencies, only the longer Kcna2 isoform was observed in the ear. In both cases, sequencing PCR products shows that both "novel" isoforms appear to be 3 ' UTR variants and do not alter the coding sequence of the genes. Expression of the longer isoform of Trpm3 is also observed in kidney and liver by RT-PCR, although not detected by EST sequencing (see Supplementary Material). Expression of both Trpm3 isoforms, in all tissues examined, is detected by additional PCR amplification (data not shown), suggesting Trpm 3 is expressed at lower levels in these other organs. Our statistical analysis also shows significantly higher expression of the shorter (known) Trpm3 isoform in the ear vs brain, liver, and kidney (see Supplementary Material). Increased PCR cycles reveal expression of both Kcna2 isoforms in kidney and liver, but not in the reference RNA (data not shown).

The new isoform of Kcnmal identified by our method is a smaller transcript than that previously reported in mouse. It is predicted to encode a protein with a slightly altered carboxyl terminus, changing the final eight amino acids from RDKQNRKEMVYR to RDKQKYVQEERL. Interestingly, the PCR primers chosen to amplify the known variant of mouse Kcnmal amplify a slightly longer product from cochlea as compared to the other tissues. Sequencing of the PCR products revealed that the band observed in the cochlea is $29 \mathrm{bp}$ longer than the other bands due to alternative splicing and inclusion of a small exon. The resulting frameshift creates a longer carboxyl terminus of the protein, replacing the final eight amino acids with RDKQNATRMTRMGQAEKKWFTDEPDNAYPRNI QIKPMSTHMANQINQYKSTSSLIPPIREVEDEC. Similar isoforms were reported previously in rat cochlea (Langer et al. 2003), and while this manuscript was under review, Beisel et al. (2007) reported the same variants in mouse inner ear validating our findings. Our sequences have since been submitted to GenBank (accession numbers EF490432 and EF473653). No other relevant mRNA sequence is available in the GenBank for mouse, and the M. musculus genome is not properly annotated.

\section{DISCUSSION}

Computational procedures were developed to identify genes of particular function by mapping the entire genome and applied to ESTs from a selected collection of inner ear cDNA libraries. We presented all ion channel genes including their possible splice variants identified by high-throughput methods in human, mouse, rat, and zebrafish, but focused on

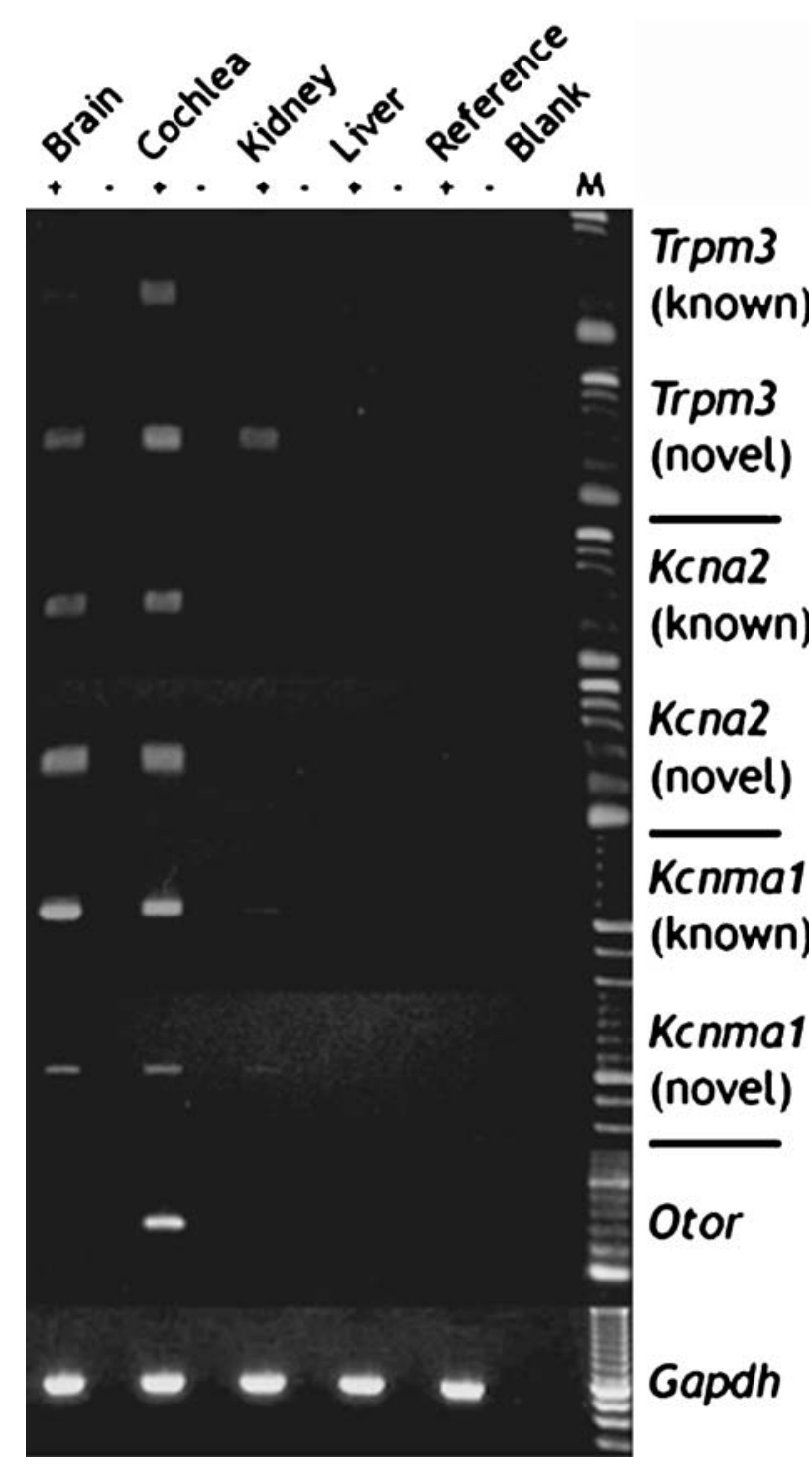

FIG. 3. RT-PCR products illustrate that both the "known" and "novel" splice variants of Trpm3, Kcna2, and Kcnma1 can be detected in mouse RNAs derived from various tissues. Control genes included Otor, found only in inner ear, and Gapdh, which is ubiquitous in these tissues. The presence or absence of reverse transcriptase enzyme in the RT reaction is indicated by $+/-$, thus, controlling for genomic contamination. Blank indicates no sample. $M$ is a $100-b p$ marker.

genes reproducibly found in human cochlea and mouse inner ear. Obviously, there are natural fluctuations in gene expression in the cell, and the accuracy of expressed gene counts improves as more data become available. While the majority of our analyses produce the same results as UniGene or other gene-indexing tools, a significant difference lies in our ability to identify novel transcript variants. Our results are necessarily biased toward the 3 ' end of genes because the cDNA libraries analyzed were oligo $\mathrm{d}(\mathrm{T})$ primed and not full length. Even with this 
TRPM3

(a)

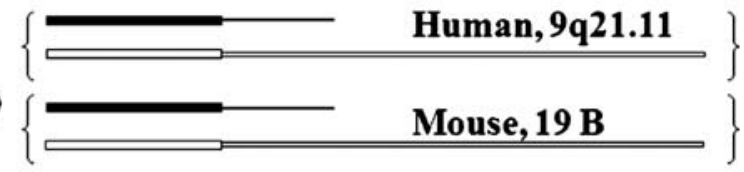

(b)

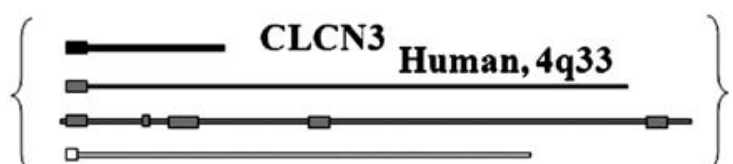

(c)
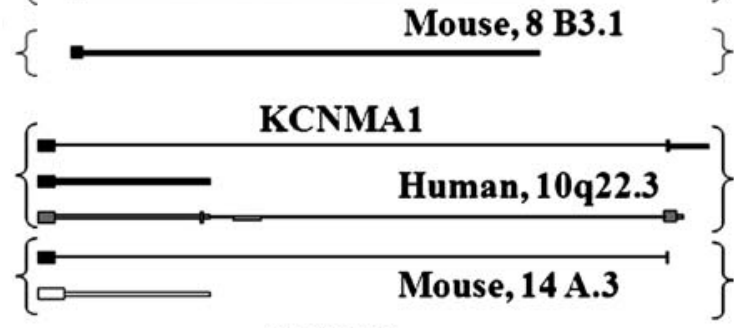

(d)
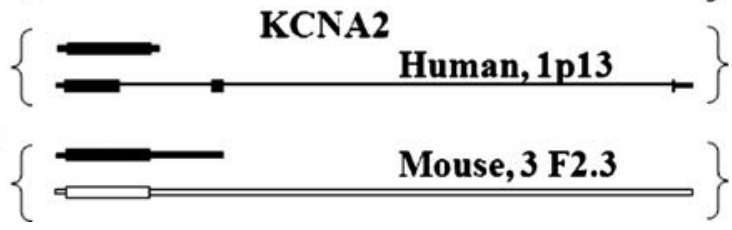

FIG. 4. Schematic representation of human and mouse ion channel gene isoforms aligned to the human genome. Each schematic shows only the most $3^{\prime}$ exon(s) and/or the $3^{\prime}$ UTR. a Human and mouse ESTs align to each other and to a region about 4,000 nt downstream of TRPM3. The last exon of the known gene and downstream regions of human and mouse gene aligned to the human genome are shown. b Novel CLCN3 splice variant, predicted for the human cochlea based on EST analysis of the human fetal cochlear library, aligns to the known Clcn3 mouse gene. AceView and ECgene predictions are also shown (light blue). c 3' end of KCNMA1 gene. A shorter UTR isoform is predicted for mouse. $\mathbf{d}$ The novel Kcna2 splice variant aligns to a human RefSeq mRNA BC043564 annotated as KCNA2. Black Verified genes (RefSeq, GenBank, UniProt, UCSC), gray variants predicted by Ensemble, AceView, Vega or ECgene, White (black contour) indicates gene variants predicted in this work based on EST and polyadenylation signal analysis, wide rectangle coding sequence, narrow rectangle 3' UTRs, solid line introns, broken line regions of poor alignment or uncertain sequence connection. Note that our predictions are only for $3^{\prime}$ regions.

limitation, we have identified and experimentally confirmed several novel variants among genes expressed in the inner ear. By using the EST mapping technique, we find that nearly half the ion channel genes identified in both the human cochlear and mouse organ of Corti cDNA libraries have previously unannotated variants. It is reasonable to expect that alternative transcripts differ in their expression patterns (Yura et al. 2006).

\section{Limitations of the method}

The existing inner ear EST datasets are not representative solely of inner ear receptor cells, as they comprise only about $1 \%$ of the inner ear. While these data are expected to capture any genes with the highest level of expression, limitations are still set by the types and number of datasets screened. For example, we are limiting ourselves to some 15 genes when examining only ion channels reliably expressed in both human and mouse inner ear EST collections. If we look at ion channel transcripts available in cDNA libraries of at least two vertebrate organisms (human, mouse, rat, zebrafish), the gene count increases to 60. If we select ion channel genes identified in either human cochlea or mouse organ of Corti, the list of ion channel genes increases to 83 (78 if we exclude potential genomic contaminations). After addition of all other available cDNA libraries of the inner ear from human, mouse, rat, and zebrafish, the number of ion channel genes increases to 197 .

As with any experimental system, different techniques can yield different results. Some ion channel genes were not identified by EST-based methods despite strong experimental evidence of their presence in microarrays, MPSS, and RT-PCR studies. For example, we did not find 18 genes in any of the inner ear EST libraries of the 36 ion channel genes detected in a mouse hair cell microarray experiment (Rivolta et al. 2002). Furthermore, the expression of over 50 ion channel genes not found by ESTsequencing was detected in inner ear tissues by microarrays or MPSS. In addition, RT-PCR experiments revealed at least eleven ion channel genes that have never been identified in any existing inner ear cDNA libraries, nor detected by microarray and MPSS experiments. These are KCNN1 (Nie et al. 2004), KCNN2 (Matthews et al. 2005), KCNQ2 and KCNQ3 (Liang et al. 2006), SCN2A (Chabbert et al. 2003), SCN5A (Wooltorton et al. 2007), TRPC2, TRPM5, PKD2L1, MCOLN3 (Cuajungco et al. 2007), and TRPV1 (Peters et al. 2007). Thus, ESTbased methods might miss up to $20 \%$ of expressed genes even if the library size is close to 20,000 sequences. Obviously, low abundant genes may easily be lost in tag sampling unless the sample is large enough, and in MPSS, the tag is placed close to the $3^{\prime}$ end (Wang et al. 2005; Chen and Rattray 2006). Microarrays detect only those genes that are present on the DNA chip, although their reliability is expected to improve with increased coverage of all possible gene splice variants. Genes with statistically significant levels of expression in microarray experiments may represent less than $70 \%$ of all actually expressed genes (Draghici et al. 2006). We find also that RT-PCR may give false negative results, possibly because of varied expression during different developmental stages or different experimental conditions (e.g., due to RT-PCR inhibitors). 
In the following discussion, we relate only some of our findings to the experimental inner ear literature because a comprehensive review of all the findings is beyond the scope of this paper.

\section{Synopsis of differential gene expression} in the inner ear

Our data show that $\mathrm{K}^{+}$channels have the highest expression levels in the ear, followed by nonselective cation channels, and then by $\mathrm{Ca}^{2+}$ and nonselective anion channels, which are expressed at the lowest levels. We observed a wider variety of voltage-gated channels than purely ligand-gated channels. Amiloride-sensitive cation channels, for example, are expressed in low numbers in both mouse and rat inner ear cDNA libraries, but are not detected in the human cochlea by EST analysis.

\section{$\mathrm{K}+$ channels}

Cells of the inner ear differ from most other signalconducting cells in their elevated use of $\mathrm{K}^{+}$ions, highly concentrated in the endolymph that baths the apical regions of the sensory cells. Thus, $\mathrm{K}^{+}$channels have a significant role in regulating $\mathrm{K}^{+}$ion movement from the cells of the stria vascularis through the sensory cells where voltage and ligand-gated channels fine-tune the transduced signal. Thus, there is a host of different $\mathrm{K}^{+}$channel types.

The large conductance $\mathrm{Ca}^{2+}$-activated $\mathrm{K}^{+}$channel $\left(\mathrm{K}_{\mathrm{Ca} 1.1}\right.$, also called BK or MaxiK), has been studied extensively in the inner ear. The BK channel contributes to frequency tuning in hair cells of nonmammalian vertebrates, whereas in mammals, recent findings in BK knockout mice reveal no hearing loss, but a decreased sensitivity to noise (Fettiplace and Crawford 1980; Crawford and Fettiplace 1981; Lewis and Hudspeth 1983; Fuchs and Evans 1988; Fuchs et al. 1988; Ramanathan et al. 1999; Pyott et al. 2007). Despite these differences, a gene that encodes the $\alpha$-subunit, KCNMA1, contains multiple splice variants in both mammalian and nonmammalian hair cells (Navaratnam et al. 1997; Rosenblatt et al. 1997; Jones et al. 1998; Ramanathan et al. 1999; Langer et al. 2003; Beisel et al. 2007). However, the mammalian variants are not annotated in the mouse and rat genomes. Only one KCNMA1 gene variant was detected by mapping of the human and mouse ESTs, a shorter isoform annotated in human as transcript variant II (NM_002247) and previously unannotated in mouse. A short isoform of a KCNMA-like gene in zebrafish was also identified (data not shown). A second KCNMA1 transcript variant was revealed fortuitously upon PCR amplification of the "known" transcript from mouse tissues.
Orthologs of all of the above KCNMA1 transcript variants are reported in mouse (Butler et al. 1993; Beisel et al. 2007) and rat cochlea (Langer et al. 2003), along with several other alternative splice variants of KCNMA1. These transcript variants, however, were not annotated in the mouse and rat genomes nor were corresponding mouse mRNA sequences available in NCBI's Entrez databases before our submissions (accession numbers EF490432 and EF473653).

A few members of the various $\mathrm{Kv}$ subfamilies were reported experimentally for the inner ear. These include Kv1.2 (KCNA2), which was recently immunolocalized to the vestibular dark cells and sensory epithelium of both human and mouse vestibular tissues; Kv1.4 and Kv1.5 were absent (Hotchkiss et al. 2005). We identified KCNA2 in both human and mouse, and $\operatorname{Kv} \beta 1.2$, also reported by Hotchkiss et al. (2005), in the larger mouse dataset. KCNA2 is present as an extended isoform in both datasets. Our analysis suggests that the new isoform has a longer UTR than the canonical form, potentially with a previously unrecognized role in translational regulation. $K C N B 1$, found in the mouse dataset was identified previously by PCR in X. laevis inner ear (Varela-Ramirez et al. 1998), while KCNC1 was immunolocalized previously in mouse spiral ganglion (Adamson et al. 2002) and developing chick cochlear ganglion and hair cells (Zhou et al. 2001). Absent from cDNA libraries was Kv4.2 (KCND2), which is found in chick and mouse cochlear ganglion and hair cells (Adamson et al. 2002; Rivolta et al. 2002; Sokolowski et al. 2004).

Potassium currents through inward rectifier $\mathrm{K}^{+}$ channels contribute to hearing. Loss of expression of a representative of this two-transmembrane (2 TM) domain subfamily $\left(K_{\mathrm{ir}}\right), K C N J 10$, causes deafness by abolishing the endocochlear potential (Wangemann et al. 2004). We observed expression of KCNJ10 in both human cochlea and mouse inner ear, while KCNJ16 was expressed in all human and mouse datasets. RT-PCR experiments showed KCNJ10 present in guinea pig cochlea from ED3 to adulthood (Jin et al. 2006).

$K C N K$ members were detected in several datasets. This $\mathrm{K}^{+}$selective leak channel passes larger outward than inward currents due to open channel rectification (Plant et al. 2005). TWIK-1 (KCNK1) and TWIK-2 (KCNK6) were found previously in the rodent inner ear using RT-PCR and immunolocalized to the strial and dark cells of the cochlea and vestibule, respectively (Nicolas et al. 2003; Mhatre et al. 2004). KCNK6 is a positional candidate for DFNA4, a form of autosomal dominant nonsyndromic hereditary hearing loss. TREK-1 (KCNK2) was detected previously in rat cochlea using RT-PCR and immunolocalized to both sensory and supporting cells (Kanjhan et al. 2004). 
We identified gene variants of a protein that contains an amino terminal similar to those found in Shaker channels. KCTD12 is an intronless gene that appears to have predominant fetal expression in the human cochlea (Resendes et al. 2004). Three splice variants of KCTD12 were identified in both human and mouse datasets, with the longest transcript being the most abundant. These splice variants differ in the UTR, which has several polyadenylation signals. The molecular role of this gene in the inner ear remains unknown, despite being a statistically significant differentiator of ear libraries vs all other tissues. KCTD12 is annotated as a gene with "voltagegated $\mathrm{K}^{+}$channel activity" [its GO evidence code is "inferred from electronic annotation" (IEA)] in human, mouse, and zebrafish genomes. This gene family encodes proteins with motifs akin to the tetramerization (T1) domain of $\mathrm{Kv}$ channels. This domain regulates $\alpha$ subunit initiation assembly and biophysical properties ( $\mathrm{Li}$ et al. 1992; Bixby et al. 1999; Zerangue et al. 2000; Quirk and Reinhart 2001; Yi et al. 2001) and interacts with $\beta$-subunits (Gulbis et al. 2000) that regulate $\alpha$ function and surface expression (Accili et al. 1997a, b; Bahring et al. 2001; Lazaroff et al. 2002). However, any similarity to a functional ion channel needs additional verification.

\section{$\mathrm{Ca}^{2+}$ and $\mathrm{Na}^{+}$channels}

Our data suggest that $\mathrm{Ca}^{2+}$ and $\mathrm{Na}^{2+}$ channels are expressed in relatively lower numbers in the inner ear. High voltage-activated channel subunits CACNA1E (Cav1.2, $\alpha 1 \mathrm{C}$ ) and CACNA1D (Cav1.3, $\alpha 1 \mathrm{D})$ (L type) are present in both mouse and rat, while several other subunits such as the intermediate voltage-activated CACNA1E (R-type channel; Cav2.3) were detected only in mouse. The L-type $\mathrm{Ca}^{2+}$ channel is found in the hair cells of various mammalian and nonmammalian inner ears (Kollmar et al. 1997; Ramakrishnan et al. 2002; Bao et al. 2003; Michna et al. 2003; Dou et al. 2004; Liang et al. 2004; Roche et al. 2005), where its loss in the cochlea leads to deafness (Platzer et al. 2000). The R-type $\mathrm{Ca}^{2+}$ channel (CACNA1E, Cav2.3, $\alpha 1 \mathrm{E})$ was localized to the outer hair cells and their underlying nerves in guinea pig (Green et al. 1996; Layton et al. 2005), whereas in mouse, it appears in multiple structures during development (e.g., spiral bundle and efferent fibers), but only at the base of the outer hair cells in adult (Waka et al. 2003). We identified only one $\mathrm{Ca}^{2+}$ channel gene, coding for the low voltage-gated, T-type, $\alpha 1 \mathrm{G}$ subunit $(C A C N A 1 G)$, in both human and mouse libraries. $I_{\mathrm{CaT}}$ is found briefly during different stages of development in the cochlear ganglion and hair cells of the chick (Jimenez et al. 1997; Sokolowski 2006; Levic et al. submitted). Both human and mouse libraries used in the present study are from fetal and late neonatal stages, respectively, suggesting a reason for detection in these libraries. $\mathrm{Ca}^{2+}$ channel subunits $\alpha 1 \mathrm{~A}(\mathrm{P} / \mathrm{Q}$ type) and $\alpha 1 \mathrm{~B}$ (L and $\mathrm{N}$ type) were found in a rat vestibular library (Roche et al. 2005), while $\mathrm{P}$ and $\mathrm{Q}$ types were reported in recordings from chick embryonic cochlear ganglion cells (Jimenez et al. 1997). Other $\mathrm{Ca}^{2+}$ channel subunits, for which there was no strong and consistent amplification, such $\alpha 1 S, \beta 2$, and $\gamma$, were never found in any of the available inner ear cDNA libraries, nor detected by microarray experiments.

Voltage-gated $\mathrm{Na}^{+}$channel genes $(S C N)$ detected included SCN1A, 3A, 7A, 10A, 8AA, 1B, and $4 B . \mathrm{Na}^{+}$ channels appear to have only a transitory role in some species. They are expressed in rat outer hair cells on postnatal days $0-9$, but expressed barely by day 18 (Oliver et al. 1997). In mouse inner hair cells, $\mathrm{Na}^{+}$current (potential candidate Nav1.7; SCN9A) is present as early as ED16.5 and disappears by the onset of hearing on postnatal day 12 (Marcotti et al. 2003). In comparison, spiral ganglion cells of adult mouse are immunoreactive for Nav1.2 (SCN2A) and Nav1.6 (SCN8A) (Hossain et al. 2005). Previously, $S C N 2 A$ and SCNA3A were suggested as candidate genes for deafness at the DFNA16 locus; the evidence, however, is inconclusive (Kasai et al. 2001). In addition, both Nav1.2 (SCN2A) and Nav1.6 (SCN8A) were identified using single cell RT-PCR on rat utricular hair cells (Chabbert et al. 2003), while Nav1.5 (SCN5A) was reported recently using electrophysiology, RT-PCR, and immunolocalization (Wooltorton et al. 2007).

\section{TRP channels}

The molecular basis of mechanotransduction in hair cells of the inner ear remains to be elucidated fully (Clapham 2003; Kung 2005). TRPA1 channels were initially thought to be the holy grail of auditory transduction channels in mammals (Corey et al. 2004), as another member of this superfamily, TRPN1, had been discovered previously in the hair cells of zebrafish (Sidi et al. 2003). More recent studies in mammals reported contradictory evidence for TRPA1 (Bautista et al. 2006), although a candidate may still be found among this superfamily (see Cuajungco et al. 2007 for review). Our data show that three sets of ESTs from the human dataset align to orthologous TRP genes in mouse: TRPM3, TRPM7, and TRPC4A. Several TRPM3 ESTs align to a region about 4,000 nucleotides (nt) downstream of the human TRPM3 gene and about 2,000 nt downstream of the mouse TRPM3 gene, suggesting the presence of a longer 3 ' UTR than previously described. TRPM3 has 24 exons spanning over 500,000 nucleotides in both human and mouse genomes. Multiple alterna- 
tively spliced transcripts were predicted for TRPM3, and it seems likely that various TRPM3 isoforms might be expressed in the inner ear. TRPM3 splice variants detected by this analysis are not hearingunique, as ESTs from eye, brain, kidney, and other tissues co-align with ESTs from the inner ear. Our RT-PCR experiments revealed that the predicted "novel" variant of TRPM3 is, indeed, present in relevant tissues. TRPV1 channel not revealed by high-throughput experiments was identified previously by PCR (Kitahara et al. 2005). TRPV2 was identified recently by MPSS analysis of mouse inner ear (Peters et al. 2007).

\section{Anion channels}

Nonselective anion channels were expressed at the lowest levels. In the inner ear, $\mathrm{Cl}-$ channels are found both in sensory and non-sensory tissues (Marcus and Marcus 1989; Wangemann and Marcus 1992; Ando and Takeuchi 2000). One of the novel human Clchannel variants identified in this work, $C L C N 3$, has a longer 3 ' UTR than the classical variant and aligns to the known isoform of mouse CLCN3. Analysis of expressed human sequences from the GenBank database shows that the longer isoform is not cochlea specific. Other members identified include CLIC5 and CLCNKA and CLCNKB. CLIC5 is found in hair cell stereocilia, its loss leads to hearing deficiency in mouse knockouts (Gagnon et al. 2006). The latter two are functionally expressed in non-sensory tissues of the inner ear and the kidney (Ando and Takeuchi 2000; Hebert 2003; Maehara et al. 2003; Qu et al. 2006), although, there is some evidence for expression of the Clc-K1 channel (CLCNKA) in the outer hair cells (Kawasaki et al. 2000). Loss of hearing is associated with Bartter's syndrome type IV, which is the result of mutations in a $\beta$ subunit, barttin $(B S N D)$, a protein that gives rise to significant $\mathrm{Cl}^{-}$ channel activity when coexpressed with either CLCNKA or CLCNKB (Birkenhager et al. 2001; Estevez et al. 2001; Hebert 2003).

\section{Ligand-gated channels}

Acid-sensing channels are potential candidates for mechanosensitive transduction in the stereocilia of the inner ear (Corey 2006). ACCN1, 2, and 3 were present in rodent EST libraries. PCR studies revealed expression in the spiral ganglion and fibers of the mouse inner ear (Hildebrand et al. 2004). Functionally, ACCN3 mouse knockouts show an increase in hearing thresholds from 2 to 3 months. However, there was no mutation of $A C C N 3$ in a family with DFNB13 hearing loss, despite ACCN3 mapping to the same chromosomal region as DFNB13. Deletions of other members, such as Asic2 (ACCN2), do not produce deafness in mice; although this mutation decreases spiral ganglion responses and susceptibility to noise (Peng et al. 2004). In comparison, Asic1b (ACCN1) channels are localized to the base of the stereocilia, but its function in the inner ear is not known (Ugawa et al. 2006).

We detected CHRNA4, 7, 9, and 10 in our study. A nicotinic sensitive ACh receptor that allows the influx of cations such as $\mathrm{Ca}^{2+}$ mediates efferent inhibition in the outer hair cells (Fuchs and Murrow 1992; Hiel et al. 2000; Marcotti et al. 2004; Gomez-Casati et al. 2005). Both $\alpha 9$ (CHRNA9) and $\alpha 10$ (CHRNA10) subunits contribute to the formation of this heteromeric channel (Gomez-Casati et al. 2005; Plazas 2005). In our study, CHRNA9 was detected in one normalized mouse cDNA library and previously by PCR (Nie et al. 2004). CHRNA10 (nicotinic ACh receptor $\alpha 10$ ) was cloned previously from human ear and lymph tissue (Lustig et al. 2001).

GABRA 1 and 2 of the gamma-aminobutyric acid (GABA) receptor genes were detected in rat and mouse databases, respectively. Sequences were absent in human cDNA libraries, whereas GABRA1, 2, and 3 (GABA A $\alpha 1$, 2, and 3 subunits) were detected also in mouse microarrays. GABA receptors modulate efferents in the cochlea. Recent studies show that mutations in mice of GABA A $\alpha$ and $\beta$ (GABRB) affect hearing differently (Maison et al. 2006). Those with mutations of the $\alpha 1,2,6$, and $\Delta$ subunits had normal hearing, whereas those with mutations of $\alpha 5$, $\beta 2$, and 3 had elevated hearing thresholds suggestive of outer hair cell dysfunction.

We found only one glutamate receptor present in both human and mouse cDNA libraries, GRIA4 (glutamate AMPA4). Excitatory postsynaptic currents are carried by AMPA receptor subunits (Glowatzki and Fuchs 2002) located postsynaptically on afferent terminals that innervate the inner hair cells. Immunogold labeling of AMPA receptor subunits in rat (GluR1-4), localize Glu2/3 and 4 postsynaptically on the afferent end terminals (Matsubara et al. 1996), whereas in situ hybridization studies in guinea pig suggest GluR2 (GRIA2) and 3 (GRIA3) mRNA expression in the spiral ganglion neurons and GluR4 (GRIA4) in the glia (Safieddine and Eybalin 1992). Presently, only immunoreactivity of Glu2 and 3 was observed in the inner ear (spiral ganglion) of mouse.

\section{CONCLUSION}

Ion-channel-mediated signal transduction in the ear is very complex and requires investigation in the context of many other interactions and pathways. This analysis is a first step toward this goal, as it identifies 
the most highly expressed and conserved ion channels in the ear, across multiple species. We show that large-scale experiments identify many but not all ion channels expressed in the inner ear. Moreover, we estimate that over half of the ion channel genome is expressed during the lifetime of the inner ear. All ion channels listed herein are present in other tissues (most often in the brain), illustrating the conservation of components among different "decision making processes" of cells receiving and transmitting electrical and mechanical signals.

Similarities between sequences of gene variants expressed in the ear are striking when comparing human and mouse, and new variants reported here and elsewhere are found in the analogous tissues of both species. These splice variants are observed in other tissues, often displaying a similar pattern of expression, suggesting the importance of transcriptional and translational regulation of ion channel genes in the inner ear, and analogously, in other organs and tissues as well. The main difference between the inner ear and other signal-conducting organs appears not to be in the specific variants of ion channel genes, but in their relative expression levels.

\section{ACKNOWLEDGEMENTS}

The authors thank Bechara Kachar of National Institute on Deafness and other Communication Disorders (NIDCD/ $\mathrm{NIH}$ ) for permission to use the complete mouse organ of Corti sequence dataset and wish to recognize partial support of this research by NIDCD grant DCO3402 (to C.C.M.). B.H.A.S. is partially supported by NIDCD DC04295.

\section{REFERENCES}

Accili EA, Kiehn J, Wible BA, Brown AM. Interactions among inactivating and noninactivating Kvbeta subunits, and Kvalpha1.2, produce potassium currents with intermediate inactivation. J. Biol. Chem. 272:28232-28236, 1997a.

Accili EA, Kiehn J, Yang Q Wang Z, Brown AM, Wible BA. Separable Kvbeta subunit domains alter expression and gating of potassium channels. J. Biol. Chem. 272:25824-25831, 1997b.

Ackerman MJ, Clapham DE. Ion channels-basic science and clinical disease. N. Engl. J. Med. 336:1575-1586, 1997.

Adamson CL, Reid MA, Mo ZL, Bowne-English J, Davis RL. Firing features and potassium channel content of murine spiral ganglion neurons vary with cochlear location. J. Comp. Neurol. 447:331-350, 2002.

Ando M, Takeuchi S. mRNA encoding 'ClC-K1, a kidney $\mathrm{Cl}(-)$ channel' is expressed in marginal cells of the stria vascularis of rat cochlea: its possible contribution to $\mathrm{Cl}(-)$ currents. Neurosci. Lett. 284(3):171-174, 2000.
Ashсroft FM. From molecule to malady. Nature 440:440-447, 2006. Ashmore J. Biophysics of the cochlea-biomechanics and ion channelopathies. Brit. Med. Bull. 63:59-72, 2002.

Ayoubi TA, Van De Ven WJ. Regulation of gene expression by alternative promoters. FASEB J. 10(4):453-460, 1996.

Bahring R, Milligan CJ, Vardanyan V, Engeland B, Young BA, Dannenberg J, Waldschutz R, Edwards JP, Wray D, Pongs O. Coupling of voltage-dependent potassium channel inactivation and oxidoreductase active site of Kvbeta subunits. J. Biol. Chem. 276(25):22923-22929, 2001.

Bao H, Wong WH, Goldberg JM, Eatock RA. Voltage-gated calcium channel currents in type I and type II hair cells isolated from the rat crista. J. Neurophysiol. 90:155-164, 2003.

Bautista DM, Jordt SE, Nikai T, Tsudura PR, Read AJ, Poblete J, Yamoah EN, Basbaum AI, Julius D. TRPAl mediates the inflammatory actions of environmental irritants and proalgesic agents. Cell 124:1269-1282, 2006.

Beisel KW, Shiraki T, Morris KA, Pompeia C, Kachar B, Arakawa T, Bono H, Kawai J, Hayashizaki Y, Carninci P. Identification of unique transcripts from a mouse full-length, subtracted inner ear cDNA library. Genomics 83:1012-1023, 2004.

Beisel KW, Rocha-Sanchez SM, Ziegenbein SJ, Morris KA, Kai C, Kawai J, Carninci P, Hayashizaki Y, Davis RL. Diversity of Ca(2+)activated $\mathrm{K}(+)$ channel transcripts in inner ear hair cells. Gene 386:11-23, 2007.

Birkenhager R, Otto E, Schurmann MJ, Vollmer M, Ruf EM, MaierLutz I, Beekmann F, Fekete A, Omran H, Feldmann D, Milford DV, Jeck N, Konrad M, Landau D, Knoers NV, Antignac C, Sudbrak R, Kispert A, Hildebrandt F. Mutation of BSND causes Bartter syndrome with sensorineural deafness and kidney failure. Nat. Genet. 29:310-314, 2001.

Bixby Ka, Nanao MH, Shen NV, Kreusch A, Bellamy H, Pfaffinger PJ, CHOE S. $\mathrm{Zn}^{2+}$-binding and molecular determinants of tetramerization in voltage-gated $\mathrm{K}_{+}$channels. Nat. Struct. Biol. 6:38-43, 1999.

Bradding P, Okayama Y, Kambe N, Saito H. Ion channel gene expression in human lung, skin, and cord blood-derived mast cells. J. Leukoc. Biol. 73:614-620, 2003.

Butler A, Tsunoda S, McCobb DP, Wei A, Salkoff L. mSlo, a complex mouse gene encoding "maxi" calcium-activated potassium channels. Science 261:221-224, 1993.

Casimiro MC, Knollmann BC, Ebert SN, Vary JC Jr, Greene Ae, Franz Mr, Grinberg A, Huang SP, Pfeifer K. Targeted disruption of the Kcnql gene produces a mouse model of Jervell and LangeNielsen Syndrome. Proc. Natl. Acad. Sci. 98:2526-2531, 2001.

Chabbert C, Mechaly I, Sieso V, Giraud P, Brugeaud A, Lehouelleur J, Couraud F, Valmier J, Sans A. Voltage-gated Na+ channel activation induces both action potentials in utricular hair cells and brain-derived neurotrophic factor release in the rat utricle during a restricted period of development. J. Physiol. 553:113123, 2003.

Chen M, Rattray M. Analysis of tag position bias in MPSS technology. BMC Genomics 7:77, 2006.

CLAPHAM DE. TRP channels as cellular sensors. Nature 426:517-524, 2003.

Coetzee WA, Amarillo Y, Chiu J, Chow A, Lau D, McCormack T, Moreno H, Nadal MS, Ozaita A, Pountney D, Saganich M, VegaSaenz de Miera E, Rudy B. Molecular diversity of K+ channels. Ann. N Y Acad. Sci. 868:233-285, 1999.

Coimbra RS, Weil D, Brottier P, Blanchard S, LeVi M, Hardelin JP, Weissenbach J, Petit C. A subtracted cDNA library from the zebrafish (Danio rerio) embryonic inner ear. Genome Res. 12:1007-1011, 2002.

COREY DP. What is the hair cell transduction channel? J. Physiol. 576(Pt 1):23-28, 2006.

Corey DP, Garcia-Anoveros J, Holt JR, Kwan Ky, Lin SY, Vollrath ma, Amalfitano A, Cheung ElM, Derfler BH, Duggan A, 
Geleoc GSG, Gray PA, Hoffman MP, Rehm HL, Tamasauskas D, ZHANG DS. TRPAl is a candidate for the mechanosensitive transduction channel of vertebrate hair cells. Nature 432:723730, 2004.

Coucke PJ, Van Hauwe P, Kelley PM, Kunst H, Schatteman I, Van Velzen D, Meyers J, Ensink RJ, Verstreken M, Declau F, Marres H, Kastury K, Bhasin S, McGuirt WT, Smith RJ, Cremers CW, Van de Heyning P, Willems PJ, Smith SD, Van Camp G. Mutations in the KCNQ4 gene are responsible for autosomal dominant deafness in four DFNA2 families. Hum. Mol. Genet. 8:13211328, 1999.

Crawford AC, Fettiplace R. An electrical tuning mechanism in turtle cochlear hair cells. J. Physiol. 312:377-412, 1981.

Cujungco MP, Grimm C, Heller S. TRP channels as candidates for hearing and balance abnormalities in vertebrates. Biochim Biophys Acta. 2007, DOI 10.1016/j.bbadis.2007.01.002

DAvIS RL. Gradients of neurotrophins, ion channels, and tuning in the cochlea. Neuroscientist 9:311-316, 2003.

Dou H, Vazquez Ae, Namkung Y, Chu H, Cardell EL, Nie L, Parson S, Shin HS, YамоAн EN. Null mutation of alpha1D Ca2+ channel gene results in deafness but no vestibular defect in mice. J. Assoc. Res. Otolaryngol. 5:215-226, 2004.

Draghici S, Khatri P, Eklund AC, Szallasi Z. Reliability and reproducibility issues in DNA microarray measurements. Trends Genet. 22:101-109, 2006.

Dumont RA, Gillespie PG. Hearing aid. Nature 424:28-29, 2003.

Estevez R, Boettger T, Stein V, Birkenhager R, Otto E, Hildebrandt F, JeNTSCH TJ. Barttin is a $\mathrm{Cl}^{-}$channel beta-subunit crucial for renal $\mathrm{Cl}^{-}$reabsorption and inner ear $\mathrm{K}^{+}$secretion. Nature 414 : 558-561, 2001.

Fettiplace R, Crawford AC. The origin tuning in turtle cochlear hair cells. Hear. Res. 2:447-454, 1980.

Fuchs PA, Evans MG. Voltage oscillations and ionic conductances in hair cells isolated from the alligator cochlea. J. Comp. Physiol. [A]. 164:151-163, 1988.

Fuchs PA, Murrow BW. A novel cholinergic receptor mediates inhibition of chick cochlear hair cells. Proc. Biol. Sci. 248:3540, 1992.

Fuchs PA, Sokolowski BH. The acquisition during development of Ca-activated potassium currents by cochlear hair cells of the chick. Proc. Biol. Sci. 241:122-126, 1990.

Fuchs PA, NagaI T, Evans MG. Electrical tuning in hair cells isolated from the chick cochlea. J. Neurosci. 8:2460-2467, 1988.

Gabashvili IS, Carter RJ, Markstein P, Giersch AB. Differential gene expression in the auditory system. Lec. Notes Comp. Sci. 3594:1-8, 2005.

Gagnon LH, Longo-Guess CM, Berryman M, Shin JB, Saylor KW, Yu H, Gillespie PG, Johnson KR. The chloride intracellular channel protein CLIC5 is expressed at high levels in hair cell stereocilia and is essential for normal inner ear function. J. Neurosci. 26:10188-10198, 2006.

Glowatzki E, Fuchs PA. Transmitter release at the hair cell ribbon synapse. Nat. Neurosci. 5:147-154, 2002.

Gomez-Casati ME, Fuchs PA, Elgoyhen AB, Katz E. Biophysical and pharmacological characterization of nicotinic cholinergic receptors in rat cochlear inner hair cells. J. Physiol. 566(Pt 1):103-118, 2005.

Green Ge, Khan KM, Beisel DW, Drescher MJ, Hatfield JS, DRESCHER DG. Calcium channel subunits in the mouse cochlea. J. Neurochem. 67:37-45, 1996.

Guda P, Bourne PE, Guda C. Conserved motifs in voltage-sensing and pore-forming modules of voltage-gated ion channel proteins. Biochem. Biophys. Res. Commun. 352:292-298, 2007.

Gulbis JM, Zhou M, Mann S, Mackinnon R. Structure of the cytoplasmic beta subunit-T1 assembly of voltage-dependent $\mathrm{K}^{+}$ channels. Science 289:123-127, 2000.
Hebert SC. Bartter syndrome. Curr. Opin. Nephrol. Hypertens. 12:527-532, 2003.

Hiel H, Luebke AE, Fuchs PA. Cloning and expression of the alpha9 nicotinic acetylcholine receptor subunit in cochlear hair cells of the chick. Brain Res. 858:215-225, 2000.

Hildebrand MS, de Silva MG, Klockars T, Rose E, Price M, Smith RJ, McGuirt WT, Christopoulos H, Petit C, Dahl HH. Characterisation of DRASIC in the mouse inner ear. Hear. Res. 190:149$160,2004$.

Holt JR, CoRey DP. Ion channel defects in hereditary hearing loss. Neuron 22:217-219, 1999.

Hossain WA, Antic SD, Yang Y, Rasband MN, Morest DK. Where is the spike generator of the cochlear nerve? Voltage-gated sodium channels in the mouse cochlea. J. Neurosci. 25:6857-6868, 2005.

Hotchkiss K, Harvey M, Pacheco M, Sokolowski B. Ion channel proteins in mouse and human vestibular tissue. Otolaryngol. Head Neck Surg. 132:916-923, 2005.

Hunter M. Accessory to kidney disease. Nature 414:502-503, 2001.

Jentsch TJ, Hubner CA, Funrmann JC. Ion channels: function unravelled by dysfunction. Nat. Cell Biol. 6:1039-1047, 2004.

Jimenez C, Gireldez F, Represa J, Garcia-Diaz JF. Calcium currents in dissociated cochlear neurons from the chick embryo and their modification by neurotrophin-3. Neuroscience 77:673-682, 1997.

Jin Z, Wei D, Jarlebark L. Developmental expression and localization of KCNJ10 K+ channels in the guinea pig inner ear. Neuroreport 17:475-479, 2006.

Jones EM, Laus C, Fettiplace R. Identification of Ca(2+)-activated $\mathrm{K}+$ channel splice variants and their distribution in the turtle cochlea. Proc. Biol. Sci. 265:685-692, 1998.

Kanjhan R, Balke CL, Housley GD, Bellingham MC, Noakes PG. Developmental expression of two-pore domain K+ channels, TASK1 and TREK-1, in the rat cochlea. Neuroreport 15:437-441, 2004.

Karnik R, Fan R, Yue M, Li D, Yang P, Majumdar A. Electrostatic control of ions and molecules in nanofluidic transistors. Nano Lett. 5:943-948, 2005.

Kasai N, Fukushima K, Ueki Y, Prasad S, Nosakowski J, Sugata K, Sugata A, Nishizaki K, Meyer NC, Smith RJ. Genomic structures of SCN2A and SCN3A-candidate genes for deafness at the DFNA16 locus. Gene 264:113-122, 2001.

KAss RS. The channelopathies: novel insights into molecular and genetic mechanisms of human disease. J. Clin. Invest. 115:1986-1989, 2005.

Kawasaki E, Hattori N, Mivamoto E, Yamashita T, Inagaki C. mRNA expression of kidney-specific ClC-K1 chloride channel in singlecell reverse transcription-polymerase chain reaction analysis of outer hair cells of rat cochlea. Neurosci. Lett. 290:76-78, 2000.

Kent WJ. BLAT-the BLAST-like alignment tool. Genome Res. 4:656-664, 2002.

Kharkovets T, Hardelin J-P, Safieddine S, Schweizer M, El-Amraoui A, Petit C, Jentsch TJ. KCNQ4, a K+ channel mutated in a form of dominant deafness, is expressed in the inner ear and the central auditory pathway. Proc. Natl. Acad. Sci. 97:4333-4338, 2000.

Kitahara T, Li HS, Balaban CD. Changes in transient receptor potential cation channel superfamily $\mathrm{V}(T R P V)$ mRNA expression in the mouse inner ear ganglia after kanamycin challenge. Hear. Res. 201:132-144, 2005.

Klockars T, Perheentupa T, Dahl HH. In silico analyses of mouse inner-ear transcripts. J. Assoc. Res. Otolaryngol. 4:24-40, 2003.

Kollmar R, Fak J, Montgomery LG, Hudspeth AJ. Hair cell-specific splicing of mRNA for the alpha1D subunit of voltage-gated $\mathrm{Ca}^{2+}$ channels in the chicken's cochlea. Proc. Natl. Acad. Sci. U. S. A. 94:14889-14893, 1997.

Kros CJ, Ruippersberg JP, Rüsch A. Expression of a potassium current in inner hair cells during development of hearing in mice. Nature 394:281-284, 1998. 
Kung C. A possible unifying principle for mechanosensation. Nature 436:647-654, 2005.

LANGer P, Grunder S, Rüsch A. Expression of $\mathrm{Ca}^{2+}$ activated BK channel mRNA and its splice variants in the rat cochlea. J. Comp. Neurol. 455:198-209, 2003.

Layton MG, Robertson D, Everett AW, Mulders WH, Yates GK. Cellular localization of voltage-gated calcium channels and synaptic vesicle-associated proteins in the guinea pig cochlea. J. Mol. Neurosci. 27:225-244, 2005.

Lazaroff MA, Taylor AD, Ribera AB. In vivo analysis of Kvbeta2 function in Xenopus embryonic myocytes. J. Physiol. 541:673683, 2002.

LEWIS RS, HudsPETH AJ. Voltage- and ion-dependent conductances in solitary vertebrate hair cells. Nature 304:538-541, 1983.

Li M, Jan YN, Jan LY. Specification of subunit assembly by the hydrophilic amino-terminal domain of the Shaker potassium channel. Science 257:1225-1230, 1992.

Liang F, Hu W, Schulte BA, Mao C, Qu C, Hazen-Martin DJ, Shen Z. Identification and characterization of an L-type Cavl.2 channel in spiral ligament fibrocytes of gerbil inner ear. Brain Res. Mol. Brain Res. 125:40-46, 2004.

Liang GH, Jin Z, Ulfendahl M, Jarlebark L. Molecular analyses of KCNQ1-5 potassium channel mRNAs in rat and guinea pig inner ears: expression, cloning, and alternative splicing. Acta Otolaryngol. 126:346-352, 2006.

Lin J, Ozeki M, Javel E, Zhao Z, Pan W, Schlentz E, Levine S. Identification of gene expression profiles in rat ears with cDNA microarrays. Hear. Res. 175:2-13, 2003.

Lipscombe D. Neuronal proteins custom designed by alternative splicing. Curr. Opin. Neurobiol. 15:358-363, 2005.

Lustig LR, Peng H, Hiel H, Yamamoto T, Fuchs PA. Molecular cloning and mapping of the human nicotinic acetylcholine receptor alpha10 (CHRNA10). Genomics. 73:272-283, 2001.

Maehara H, Okamura HO, Kobayashi K, Uchida S, Sasaki S, Kitamura K. Expression of CLC-KB gene promoter in the mouse cochlea. Neuroreport 14:1571-1573, 2003.

Maison SF, Rosahl TW, Homanics GE, Liberman MC. Functional role of GABAergic innervation of the cochlea: phenotypic analysis of mice lacking GABA(A) receptor subunits alpha 1 , alpha 2 , alpha 5 , alpha 6 , beta 2 , beta 3 , or delta. J. Neurosci. 26:10315-10326, 2006.

Mammano F, Ashmore JF. Differential expression of outer hair cell potassium currents in the isolated cochlea of the guinea-pig. J. Physiol. 496:639-646, 1996.

Marcotti W, Johnson SL, Rûsch A, Kros CJ. Sodium and calcium currents shape action potentials in immature mouse inner hair Cells. J. Physiol. 552(Pt 3):743-761, 2003.

Marcotti W, Johnson SL, Kros CJ. A transiently expressed SK current sustains and modulates action potential activity in immature mouse inner hair cells. J. Physiol. 560:691-708, 2004.

Marcus DC, Marcus NY. Transepithelial electrical responses to $\mathrm{Cl}^{-}$ of nonsensory region of gerbil utricle. Biochim. Biophys. Acta. 987:56-62, 1989.

Matsubara A, Laake JH, Davanger S, Usami S, Ottersen OP. Organization of AMPA receptor subunits at a glutamate synapse: a quantitative immunogold analysis of hair cell synapses in the rat organ of Corti. J. Neurosci. 16:4457-4467, 1996.

Matthews TM, Duncan RK, Zidanic M, Michael TH, Fuchs PA. Cloning and characterizatin of SK2 channel from chicken short hair cells. J. Comp. Physiol. A. Neuroethol. Sens. Neural. Behav. Physiol. 191:491-503, 2005.

Mhatre AN, Li J, Chen AF, Yost CS, Smith RJ, Kindler CH, Lalwani AK. Genomic structure, cochlear expression, and mutation screening of KCNK6, a candidate gene for DFNA4. J. Neurosci. Res. 75: 25-31, 2004.
Michna M, Knirsch M, Hoda J-C, Muenkner S, Langer P, Platzer J, Striessnig J, Engel J. Cav1.3 (alpha1D) $\mathrm{Ca}^{2+}$ currents in neonatal outer hair cells of mice. J. Physiol. 553:747-758, 2003.

Morris Ka, Snir E, Pompeia C, Koroleva IV, Kachar B, Hayashizaki Y, Carninci P, Soares MB, Beisel KW. Differential expression of genes within the cochlea as defined by a custom mouse inner ear microarray. J. Assoc. Res. Otolaryngol. 6:75-89, 2005.

Navaratnam DS, Bell TJ, Tu TD, Cohen EL, Oberholtzer JC. Differential distribution of $\mathrm{Ca}^{2+}$-activated $\mathrm{K}^{+}$channel splice variants among hair cells along the tonotopic axis of the chick cochlea. Neuron 19:1077-1085, 1997.

Nicolas M, Dememes D, Martin A, Kupershmidt S, Barhanin J. KCNQ1/KCNE1 potassium channels in mammalian vestibular dark cells. Hear. Res. 153:132-145, 2001.

Nicolas MT, Barhanin J, Reyes R, Dememes D. Cellular localization of TWIK-1, a two-pore-domain potassium channel in the rodent inner ear. Hear. Res. 181:20-26, 2003.

Nie L, Song H, Chen MF, Chiamvimonvat N, Beisel KW, Yamoah EN, VAZQuez AE. Cloning and expression of a small-conductance $\mathrm{Ca}(2+)$-activated $\mathrm{K}+$ channel from the mouse cochlea: coexpression with alpha9/alpha10 acetylcholine receptors. J. Neurophysiol. 91:1536-1544, 2004.

Niemeyer BA, Mery L, Zawar C, Suckow A, Monje F, Pardo LA, Stuhmer W, Flockerzi V, Ноth M. Ion channels in health and disease. EMBO Rep. 2:568-573, 2001.

Okazaki Y, Furuno M, Kasukawa T, Adachi J, Bono H, Kondo S, Nikaido I, Osato N, et al. Analysis of the mouse transcriptome based on functional annotation of 60,770 full-length cDNAs. Nature 420:563-573, 2002.

Oliver D, Plinkert P, Zenner HP, Ruppersberg JP. Sodium current expression during postnatal development of rat outer hair cells. Pflugers Arch. 434:772-778, 1997.

Peng BG, Ahmad S, Chen S, Chen P, Price MP, Lin X. Acid-sensing ion channel 2 contributes a major component to acid-evoked excitatory responses in spiral ganglion neurons and plays a role in noise susceptibility of mice. J. Neurosci. 24:10167-10175, 2004.

Peters LM, Belyantseva iA, Lagziel A, Battey JF, Friedman TB, Morell RJ. Signatures from tissue-specific MPSS libraries identify transcripts preferentially expressed in the mouse inner ear. Genomics 89:197-206, 2007.

Plant LD, Rajan S, Goldstein SA. K2P channels and their protein partners. Curr. Opin. Neurobiol. 15:326-333, 2005.

Platzer J, Engel J, Schrott-Fischer A, Stephan K, Bova S, Chen H, Zheng H, Striessnig J. Congenital deafness and sinoatrial node dysfunction in mice lacking class D L-type $\mathrm{Ca}^{2+}$ channels. Cell 102:89-97, 2000.

Plazas PV, Katz E, Gomez-Casati Me, Bouzat C, Elgoyhen AB. Stoichiometry of the alpha9alpha10 nicotinic cholinergic receptor. J. Neurosci. 25:10905-10912, 2005.

Pompeia C, Hurle B, Belyantseva ia, Noben-Trauth K, Beisel K, Gao J, Buchoff P, Wistow G, Kachar B. Gene expression profile of the mouse organ of Corti at the onset of hearing. Genomics 83:1000-1011, 2004.

Pyott SJ, Meredith AL, Fodor AA, Vazquez Ae, Yamoah EN, Aldrich RW. Cochlear function in mice lacking the bk channel alpha , beta 1 , or beta 4 subunits. J. Biol. Chem. 282:3312-3324, 2007.

Qu C, Liang F, Hu W, Shen Z, Spicer SS, Schulte BA. Expression of CLC-K chloride channels in the rat cochlea. Hear. Res. 213:7987, 2006.

Quirk JC, Reinhart PH. Identification of a novel tetramerization domain in large conductance K-Ca channels. Neuron 32:13-23, 2001.

Ramakrishnan na, Green Ge, Pasha R, Drescher MJ, Swanson GS, Perin PC, Lakhani RS, Ahsan SF, Hatfield JS, Khan KM, DrESCHER DG. Voltage-gated $\mathrm{Ca}^{2+}$ channel $\mathrm{Ca}(\mathrm{V}) 1.3$ subunit expressed in the hair cell epithelium of the sacculus of the 
trout Oncorhynchus mykiss: cloning and comparison across vertebrate classes. Brain Res. Mol. Brain Res. 109:69-83, 2002.

Ramanathan K, Michael TH, Jiang G-J, Hiel H, Fuchs PA. A molecular mechanism for electrical tuning of cochlear hair cells. Science 283:215-217, 1999.

Resendes BL, Robertson NG, Szustakowski JD, Resendes RJ, Weng Z, Morton CC. Gene discovery in the auditory system: characterization of additional cochlear-expressed sequences. J. Assoc. Res. Otolaryngol. 3:45-53, 2002.

Resendes BL, Kuo SF, Robertson NG, Giersch AB, Honrubia D, Ohara O, Adams JC, Morton CC. Isolation from cochlea of a novel human intronless gene with predominant fetal expression. J. Assoc. Res. Otolaryngol. 5:185-202, 2004.

Rivolta Mn, Halsall A, Johnson CM, Tones MA, Holley MC. Transcript profiling of functionally related groups of genes during conditional differentiation of a mammalian cochlear hair cell line. Genome Res. 12:1091-1099, 2002.

Roche JP, Wackym PA, Cioffi JA, Kwitek AE, Erbe CB, Popper P. In silico analysis of 2085 clones from a normalized rat vestibular periphery 3' cDNA library. Audiol. Neurootol. 10:310-322, 2005.

Rosenblatt KP, Sun ZP, Heller S, Hudspeth AJ. Distribution of $\mathrm{Ca}^{2+}$-activated $\mathrm{K}^{+}$channel isoforms along the tonotopic gradient of the chicken's cochlea. Neuron 19:1061-1075, 1997.

Rosenthal JJ, Gilly WF. Identified ion channels in the squid nervous system. Neurosignals 12:126-141, 2003.

Rüttiger L, Sausbier M, Zimmermann U, Winter H, Braig C, Engel J, Knirsch M, Arntz C, Langer P, Hirt B, Müller M, Köpschall I, Pfister M, Münkner S, Rohbock K, Pfaff I, Rüsch A, Ruth P, KNIPPER M. Deletion of the $\mathrm{Ca}^{2+}$-activated potassium (BK) alphasubunit but not the BK betal-subunit leads to progressive hearing loss. Proc. Natl. Acad. Sci. U. S. A. 101:12922-12927, 2004.

Safieddine S, Eybalin M. Co-expression of NMDA and AMPA/ kainate receptor mRNAs in cochlear neurones. Neuroreport 3:1145-1148, 1992.

Shieh CC, Coghlan M, Sullivan JP, Gopalakrishnan M. Potassium channels: molecular defects, diseases, and therapeutic opportunities. Pharmacol. Rev. 52:557-594, 2000.

Shrivastava IH, Bahar I. Common mechanism of pore opening shared by five different potassium channels. Biophys. J. 90:3929-3940, 2006.

Sidi S, Friedrich RW, Nicolson T. NompC TRP channel required for vertebrate sensory hair cell mechanotransduction. Science 301:96-99, 2003.

Skvorak AB, Weng Z, Yee AJ, Robertson NG, Morton CC. Human cochlear expressed sequence tags provide insight into cochlear gene expression and identify candidate genes for deafness. Hum. Mol. Genet. 8:439-452, 1999.

Sokolowski BH. Survey of inward ionic currents acquired by the cochleovestibular ganglion of the early-aged embryonic chick. J. Neurosci. Res. 83:638-646, 2006.

Sokolowski BH, Sakai Y, Harvey MC, Duzhyy DE. Identification and localization of an arachidonic acid-sensitive potassium channel in the cochlea. J. Neurosci. 24:6265-6276, 2004.

Strausberg RL, Feingold EA, Grouse lH, Derge JG, Klausner RD, Collins FS, Wagner L, Shenmen CM, Schuler GD, Altschul SF, Zeeberg B, Buetow KH, Schaefer CF, Bhat NK, Hopkins RF, Jordan H, Moore T, Max SI, Wang J, Hiseh F, Diatchenko L, Marusina K, Farmer AA, Rubin GM, Hong L, Stapleton M, Soares MB, Bonaldo MF, Casavant TL, Scheetz Te, Brownstein MJ, Usdin TB, Toshiyuki S, Carninci P, Prange C, Raha SS, Loquellano na, Peters GJ, Abramson RD, Mullahy SJ, Bosak SA, McEwan PJ,
McKernan KJ, Malek JA, Gunaratne PH, Richards S, Worley KC, Hale S, Garcia AM, Gay LJ, Hulyk SW, Villalon DK, Muzny DM, Sodergren EJ, Lu X, Gibbs RA, Fahey J, Helton E, Ketteman M, Madan A, Rodrigues S, Sanchez A, Whiting M, Madan A, Young AC, Shevchenko Y, Bouffard GG, Blakesley RW, Touchman JW, Green ED, Dickson MC, Rodriguez AC, Grimwood J, Schmutz J, Myers RM, Butterfield YS, Krzywinski MI, Skalska U, Smailus DE, Schnerch A, Schein JE, Jones SJ, Marra MA, Mammalian Gene Collection Program Team. Generation and initial analysis of more than 15,000 full-length human and mouse cDNA sequences. Proc. Natl. Acad. Sci. U. S. A. 99:16899-16903, 2002.

Sun KS, YUSPA SH. Intracellular chloride channels: critical mediators of cell viability and potential targets for cancer therapy. Curr. Pharm. Des. 11:2753-2764, 2005.

TAI KK. Ion channels as a target for drug design. Curr. Pharm. Des. 11:2669-2670, 2005.

Ugawa S, Inagaki A, Yamamura H, Ueda T, Ishida Y, KajtTa K, Shimizu H, Shimada S. Acid-sensing ion channel-1b in the stereocilia of mammalian cochlear hair cells. Neuroreport 17:1235-1239, 2006.

Varela-Ramirez A, Trujillo-Provencio C, Serrano Ee. Detection of transcripts for delayed rectifier potassium channels in the Xenopus laevis inner ear. Hear. Res. 119:125-134, 1998.

WAKa N, Knipper M, Engel J. Localization of the calcium channel subunits Cav1.2 (alpha 1C) and Cav2.3 (alpha 1E) in the mouse organ of Corti. Histol. Histopathol. 18:1115-1123, 2003.

Wang JP, Lindsay BG, Cui L, Wall PK, Marion J, Zhang J, DE PAmphilis CW. Gene capture prediction and overlap estimation in EST sequencing from one or multiple libraries. BMC Bioinformatics 6:300, 2005.

Wangemann P, Marcus DC. The membrane potential of vestibular dark cells is controlled by a large Cl-conductance. Hear. Res. 62:149-156, 1992.

Wangemann P, Itza EM, Albrecht B, Wu T, Jabba SV, Maganti RJ, Lee JH, Everett LA, Wall SM, Royaux IE, Green ED, Marcus DC. Loss of KCNJ10 protein expression abolishes endocochlear potential and causes deafness in Pendred syndrome mouse model. BMC Med. 2:30-44, 2004.

Wei A, Jegla T, Salkoff L. Eight potassium channel families revealed by the C. elegans genome project. Neuropharmacology 35:805-829, 1996.

Wooltorton JR, Gaboyard S, Hurley KM, Price SD, Garcia JL, Zhong M, Lysakowski A, Eatock RA. J. Neurophysiol. 97:16841704, 2007.

Yi BA, Minor DL JR, Lin YF, JAN YN, JAN LY. Controlling potassium channel activities: Interplay between the membrane and intracellular factors. Proc. Natl. Acad. Sci. U.S.A. 98:1101611023, 2001.

Yura K, Shionyu M, Hagino K, Hijikata A, Hirashima Y, Nakahara T, Eguchi T, Shinoda K, Yamaguchi A, Takahashi K, Itoh T, Imanishi T, Gojobori T, Go M. Alternative splicing in human transcriptome: functional and structural influence on proteins. Gene 380:6371, 2006.

Zerangue N, JAN YN, JAN LY. An artificial tetramerization domain restores efficient assembly of functional Shaker channels lacking T1. Proc. Natl. Acad. Sci. 97:3591-3595, 2000.

Zhou X, Baier C, Hossain WA, Goldenson M, Morest DK. Expression of a voltage-dependent potassium channel protein (Kv3.1) in the embryonic development of the auditory system. J. Neurosci. Res. 65:24-37, 2001. 